\title{
Antje Töpel \\ Review of research into the use of electronic dictionaries
}

\begin{abstract}
The following chapter provides a review of research literature on the use of electronic dictionaries. Because the central terms electronic dictionary and research into dictionary use are sometimes used in different ways in the research, it is necessary first of all to examine these more closely, in order to clarify their use in this research review. The main chapter presents several individual studies in chronological order. The chapter is completed by a summary.
\end{abstract}

Keywords: dictionary typology, user studies, questionnaire, experiment, test, usability study, eye-tracking, log file

Antje Töpel: Institut für Deutsche Sprache, R 5, 6-13, D-68161 Mannheim, +49-(0)621-1581434, toepel@ids-mannheim.de

\section{Clarification of terminology}

\subsection{Electronic dictionary}

The term electronic dictionary (ED) is defined by Nesi as follows:

\footnotetext{
"The term electronic dictionary (or ED) can be used to refer to any reference material stored in electronic form that gives information about the spelling, meaning, or use of words. Thus a spell-checker in a word-processing program, a device that scans and translates printed words, a glossary for on-line teaching materials, or an electronic version of a respected hard-copy dictionary are all EDs of a sort, characterised by the same system of storage and retrieval." (Nesi 2000 a: 839 ; her italics)
}

Electronic dictionaries are therefore distinguished from printed dictionaries firstly by the way in which the data are stored, and secondly by the way in which these data are accessed (cf. also Engelberg/Lemnitzer 2009: 271). In addition, MüllerSpitzer restricts the term electronic dictionary to human users, as this conveys the precondition for transferring in a meaningful way the basic properties of a printed dictionary to an electronic dictionary (cf. Müller-Spitzer 2007: 31).

The term electronic dictionary is therefore, as Nesi has already argued, a generic term for different types of electronic dictionaries. For this reason, some academics have tried to develop typologies of electronic dictionaries. A very early attempt at 
typologization can be found in Storrer/Freese (cf. Storrer/Freese 1996: $107 \mathrm{ff}$.). In this, the authors base their work on the typology of printed dictionaries developed by Hausmann (cf. Hausmann 1989). From that, they use the medium-independent criteria of number of languages and degree of specialization, according to which they differentiate between monolingual, bilingual and multilingual dictionaries, as well as between general and specialist dictionaries (which are then further subdivided). In addition to this, they add some medium-specific typological features (publication form, discreteness, hypertextualization, multimediality and access modes) in order to do justice to the medial peculiarities of electronic dictionaries.

Nesi distinguishes between four main categories of electronic dictionary - the internet dictionary, the glossary for on-line courseware, the learners' dictionary on CD-ROM und the pocket electronic dictionary (PED) (cf. Nesi 2000 a: 842 f.). However, she herself acknowledges the blurred boundaries between the individual types. Further attempts from the 1990s to typologize electronic dictionaries are presented in De Schryver (2003: 147).

Unhappy with existing attempts to typologize electronic dictionaries, De Schryver developed his own typology (cf. De Schryver 2003: $147 \mathrm{ff}$.). This is a three-tier typology, which above all places access to the dictionary at the centre (see Fig. 1). On the first level, the typology asks who accesses the dictionary - humans or machines. The second level addresses the question of what is being accessed, or the medium of the dictionary, i.e. a physical (non-electronic) object, or the electronic medium. Finally, the third level further differentiates electronic dictionaries according to place of access, i.e. storage. According to this categorization, internet dictionaries, for example, are electronic dictionaries which are networked, linked to a device, and oriented towards people.

Tono also addresses the typologization of electronic dictionaries. He distinguishes the following main types (cf. Tono 2004: $16 \mathrm{ff}$.): regular format, hyperlink format, pop-up mode interface, parallel format und pocket e-dictionaries. One criticism of this typologization is that two different criteria, namely how the content is presented and the device on which the dictionary is accessed, are mixed up together: dictionaries of the regular format type present data as in a printed dictionary, dictionaries of the hyperlink format type use hyperlinks, dictionaries of the popup mode interface type rely on pop-up menus, while dictionaries of the parallel format type display translation equivalents in parallel. In contrast, the pocket $e$ dictionary type is defined by the device on which the dictionary is accessed. Another criticism is that the typology is too strongly linked to current technologies (such as pop-ups). 


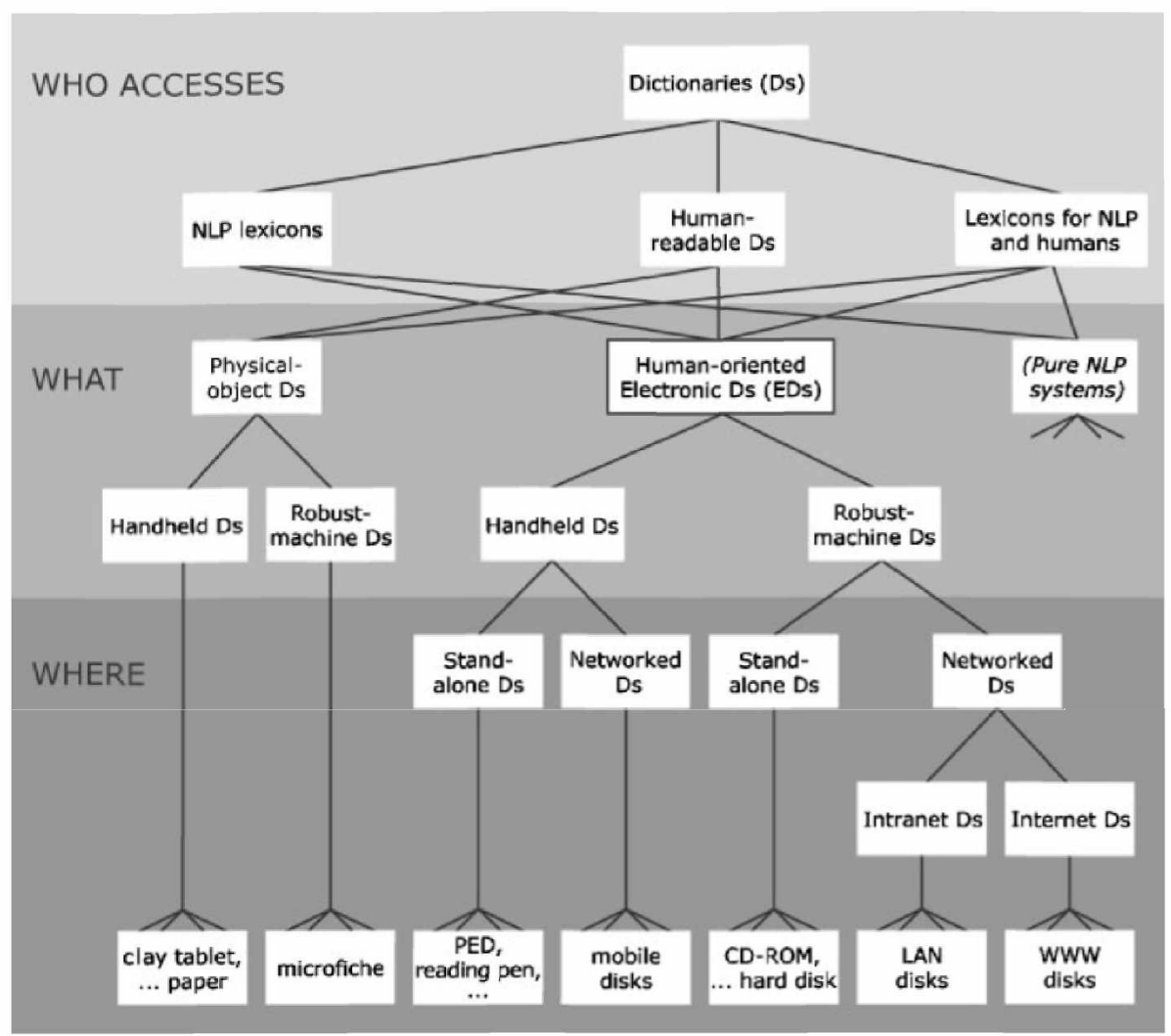

Fig. 1: Typology of dictionaries according to De Schryver (2003:150) (D = dictionary, ED = electronic dictionary, $\mathrm{LAN}=$ local area network, NLP $=$ natural language processing, $\mathrm{PED}=$ pocket electronic dictionary)

Instead of the term electronic dictionary, the expression digital dictionary is often chosen, for example by Wiegand (2010: 88). Here as well, the two terms are used synonymously. Wiegand further differentiates between digital dictionaries: 1 . he makes a distinction according to the availability of the lexicographical database (cf. Wiegand 2010: 89) between offline and online dictionaries, which are further subdivided according to type of storage medium or network service; 2 . he distinguishes between Abschlusswörterbücher ('closed' dictionaries) and Ausbauwörterbücher ('open' dictionaries) according to level of discreteness (cf. Wiegand 2010: 90 f.); 3. he distinguishes between text-based digital dictionaries and multimedia dictionaries according to the type of semiotic coding of the lexicographical database (cf. Wiegand 2010: 91). However, in the case of the differentiation (type of semiotic coding), it remains unclear why this distinction is made only in relation to electronic dictionaries, when there are printed dictionaries with illustrations as well. 
Electronic dictionaries can be presented as individual products which are independent of other dictionaries, or they can be part of a dictionary portal. A dictionary portal is

"a data structure (i) that is presented as a page or set of interlinked pages on a computer screen and (ii) provides access to a set of electronic dictionaries, (iii) where these dictionaries can also be consulted as stand-alone products" (Engelberg/Müller-Spitzer).

Dictionary portals can also be typologized, according to the type of access available, the reference structures between the dictionaries, the proprietary relationship between the portal and the dictionaries it contains, as well as the layout of the portal (cf. Engelberg/Müller-Spitzer).

As far as terminology is concerned, the present article follows De Schryver. However, it is concerned generally with research into the use of electronic or digital dictionaries - regardless of what types these are further subdivided into. Up until now, however, studies into the use of electronic dictionaries have dealt exclusively with three groups of digital dictionary: dictionaries on CD-ROM, internet dictionaries and PEDs.

\subsection{Research into dictionary use}

According to Hartmann, research into dictionary use comprises four areas: typology of dictionaries, typology of users, analysis of needs, and analysis of skills (cf. Hartmann 1987: 154). In this differentiation, Hartmann concentrates on the categorization of dictionaries and their users, as well as on the needs and skills of the users.

According to Wiegand, research into dictionary use addresses the following questions (cf. Wiegand 1987: 192 ff.): who uses a dictionary, in what way, under what external circumstances, at what moment, for how long, in what place, why, on what occasion, with what aim, with what outcome, and with what consequences? Of interest in the framework of Wiegand's action theory are therefore the subject (the user), the modality (the skills of the user), the internal context (the cognitive conditions), the external context (the context and circumstances of the action), the consequences, as well as the outcome of the action of using a dictionary (cf. Wiegand 1987: 181). Research into dictionary use should provide academic knowledge about the use of dictionaries, but here Wiegand refers only to printed dictionaries (cf. Wiegand 1998: 259). Research into the use of electronic dictionaries has also been carried out, but it obviously did not start until later than research into the use of print dictionaries, since electronic dictionaries are the more recent type. Research into dictionary use should support current as well as future lexicographical projects in improving their products: 
'If you have academic knowledge, especially if it is empirically based, about dictionary users and above all dictionary use, you can with justification improve the usefulness of new dictionaries which will be developed in the future and that of new dictionary editions, as well as that of concise versions of existing dictionaries. ${ }^{1}$ (Wiegand 1998: 259, see also Wiegand 1987: 179)

This statement, which applies to print lexicography, is relevant to an even greater degree to internet dictionaries. For, in this case, there is the possibility, at least technically, of making immediate, visible changes to the dictionary content, or to the way in which it is presented.

In the field of general dictionary research, research into dictionary use is the most recent and least developed area (cf. Wiegand 1998: $259 \mathrm{ff}$.). As well as research into dictionary use, critical, historical, and systematic research into dictionaries are three further areas of dictionary research. (cf. Wiegand 1998: 6). Research into dictionary use was started by Barnhart at the beginning of the 1960s. It was not until the 1990 s that the importance of research into dictionary use grew to such an extent that it gained the status of a separate area of research within the field of dictionary research. According to Wiegand, three areas of work are important for the further development of research into dictionary use - laying the theoretical foundations, developing the methodology and formulating fruitful questions for empirical studies (Wiegand 1998: 262).

Bergenholtz and Tarp's functional lexicographical approach sees dictionary users and their needs as the starting point for all decisions (cf. Bergenholtz/Tarp 2002: 254):

"The theory of lexicographical functions [...] is based on the idea that dictionaries are objects of use which are produced or should be produced to satisfy specific types of social need. These needs are not abstract - they are linked to specific types of user in specific types of social situation. Attempts are made to cover these needs using specific types of lexicographical data collected and made available in specific types of dictionary." (Tarp 2008: 43)

The functional approach also sees research into dictionary use as one of the four areas of dictionary research.

Empirical social research plays a particularly important role in research into dictionary use, as the latter makes use of the methodology of the former (for more detail, see the chapter by Koplenig in this volume).

If the individual suggestions by metalexicographers on possible methods of investigation in research into dictionary use are considered together, all distinguish between forms of survey, observation, and experiment or test. Some also mention

1 „Wenn man wissenschaftliche Kenntnisse, insbesondere empirisch fundierte, über die Wörterbuchbenutzer und vor allem über die Wörterbuchbenutzung hat, kann man den Nutzungswert in Zukunft zu erarbeitender neuer Wörterbücher und den von neuen Wörterbuchauflagen sowie den von gekürzten Versionen bereits vorhandener Wörterbücher mit guten Gründen erhöhen." (Wiegand 1998: 259). 
content analysis. Ultimately, metalexicographers agree on many points as far as the fundamental framework of methods for research into dictionary use is concerned. In some instances, however, there are deviations from empirical social science, for example when specific concepts from research into dictionary use do not fit into the general schema.

For this reason, the following suggestion for categorization is made, which comes from the standard techniques of data investigation in empirical social research and incorporates the specific concepts of research into dictionary use (cf. Zöfgen 1994: 39 ff.):

- Questioning

- written: questionnaire

- spoken: interview

- Observation

- self-observation: keeping records of dictionary use, thinking aloud, commentaries on dictionary use

- external observation: keeping observation records of users, camera recordings, $\log$ file analysis and eye-tracking with electronic dictionaries

- Experiment/test and

- Content analysis.

\section{Research literature on the use of electronic dictionaries}

\subsection{Overview}

Research literature on dictionary use is - seen as a whole - relatively extensive. Welker estimates the number of studies worldwide up until 2008 to be between 250 and 300 (cf. Welker 2008: 8), not to mention those that have appeared in the meantime. Because of this, Bergenholtz/Johnsen state: "From 1985 until today, so many monographs, editions and papers in journals have been published that it is difficult or even impossible to get a complete overview" (Bergenholtz/Johnsen 2005: 119). However, Wiegand is right when some years later he characterizes research into dictionary use as the least developed area within dictionary research in comparison with other research areas (cf. Wiegand 2008: 1).

How then does the situation arise, which at first glance appears to be paradoxical, that despite the fairly high number globally of studies on dictionary use, the research situation as a whole is considered to be poor? There are several reasons for this. The first lies in the complexity of the topic. For one, research into dictionary use refers to completely different types of dictionary, which vary for instance in 
medium (printed/electronic), number of languages (monolingual/bilingual/multilingual), degree of specialization (general/specialist), type of information given (pronunciation/meaning/examples/paradigms), or target group (non-native speakers/native speakers). For another, with all these dictionaries, different types of usage action can be studied, for example activities which stress the function of the dictionary in the field of production, reception or learning, or specialist actions such as translation. From the combination of the individual realizations of these two dimensions alone, a multitude of possible individual areas arises, which can be studied in the framework of research into dictionary use. Furthermore, it is not only dictionaries as the object of study as well as the particular questions which are complex, but also the methodological options for studying the dictionary as object. Depending on the investigation process used (survey, observation, experiments/tests, content analysis) and the form (e.g. scope of the study, type and number of participants), completely different approaches to the relevant questioning arise. The countless possible combinations of questions (object and type of usage action) and investigation processes mean that it is almost impossible to compare the individual studies with one another, as Welker also observes:

'After reading many research reports, what can be established is that it is difficult to generalise the results: sometimes the authors have not isolated the external factors which influence dictionary use. In each case, the results - unless a sophisticated methodology is used - can only be generalised for identical situations.' (Welker 2006 b: 225) ${ }^{2}$

It is therefore rare to find works which address the same topic and at the same time correspond in their methodological structure (cf. also Wiegand 2008: 2 and Dziemianko 2012b: 335). One of the few exceptions is Lew/Doroszewska (2009). They carried out an extended version of the study by Laufer/Hill (2000) on Polish learners of English (see section 3.1). Chen (2011) is an example of an investigation of printed dictionaries, which is oriented towards Laufer/Hadar (1997). Heid/Zimmermann's study is inspired by Bank's inquiry. The fact that, up until now, there have been only a few studies which can be compared with one another particularly applies to research into the use of electronic dictionaries, since up until now, comparatively few investigations have dealt with this still new type of dictionary. Researchers repeatedly demand, both in general and in research into electronic dictionaries in particular, that the topic be more firmly tackled and that more high-quality qualitative studies be carried out (cf. for instance Höhne 1991: 293 f., Zöfgen 1994: 36, Atkins/Varantola 1997: 36, Hartmann 2000: 385 and Hulstijn/Atkins 1998: 16). Occasional criticism of the lack of research into the use of electronic dictionaries began

2 "O que se constata após a leitura de muitos relatos de pesquisa é que os resultados dificilmente são generalizáveis: às vezes, os autores deixaram de isolar fatores externos que influenciam no uso do dicionário, e, de qualquer modo, mesmo quando se adota uma metodologia aprimorada, os resultados podem ser generalizados apenas para situações idênticas." (Welker 2006 b: 225). 
to surface at the end of the 1980 s (cf. Hartmann 1989 a: 109), although it did not become more forceful until ten years later. Nesi, for example, makes this criticism: "We still do not know much about how such dictionaries [electronic dictionaries, A. T.] are used, or how they might be used" (Nesi 1999: 63). Research into the use of digital dictionaries is "still in its infancy" (Nesi 2000 a: 845), because there are only a few studies on the topic. Loucky also stresses this, when - in the context of the research situation of the dictionary use of Japanese learners of English - he observes of internet dictionaries: "Even less available are any studies of online web dictionary use" (Loucky 2005: 390). This situation has not changed fundamentally until now, as "the dictionary users and their actions are to some extent still unknown, especially in Internet lexicography" (Simonsen 2011: 77). The special edition of the International Journal of Lexicography on the topic "Studies in Dictionary Use: Recent Developments" is an example of this: of the six studies of dictionary use it contains, only one (Tono 2011) deals explicitly with digital dictionaries. Germanlanguage literature is similarly critical of the research situation: 'User research has been carried out into only a very few online dictionaries. It is precisely here that things should change in the future.' ["Für die wenigsten Online-Wörterbücher ist Benutzerforschung betrieben worden [...]. Gerade hierzu sollte sich zukünftig etwas ändern"] (Klosa/Lemnitzer/Neumann 2008: 16; cf. also Aust/Kelley/Roby 1993: 72, Nesi 2000 b: 113, Tono 2000: 861, Winkler 2001 b: 194, Engelberg/Lemnitzer 2009: 90).

A second reason for the unsatisfactory situation in research into dictionary use is the lack of methodology in many studies (cf. Zöfgen 1994: $33 \mathrm{f}$., Hulstijn/Atkins 1998: 16, Bogaards 2003: 26, Engelberg/Lemnitzer 2009: 85 f.). Ripfel/Wiegand observe:

'Apart from a small number of exceptions, there is hardly any information in the works presented about statistical evaluation. Sometimes even the number of participants is not given! They do not even fulfil the minimum requirements of an investigation report for an empirical study. This is not just for academic, theoretical or ethical reasons, but also because for this reason, the relevance of the results and with it of the whole investigation, cannot be properly evaluated. ${ }^{3}$ (Ripfel/Wiegand 1988: 496)

In most cases, the authors of more recent studies on the subject of research into dictionary use have at their disposal a wider knowledge of methodology than in the early days of research into this subject (cf. also Lew $2011 \mathrm{a}$ : 1). However, this is not

3 „Bis auf wenige Ausnahmen werden in den vorgelegten Arbeiten kaum Angaben zur statistischen Auswertung gemacht, z. T. wird sogar die Zahl der Probanden nicht genannt! Sie genügen damit nicht einmal den Minimalanforderungen an einen Untersuchungsbericht über eine empirische Erhebung. Dies ist nicht nur aus wissenschaftstheoretischen oder -ethischen Gründen bedauerlich, sondern auch [sic!] weil dadurch die Relevanz der Ergebnisse und damit der ganzen Untersuchung schlecht eingeschätzt werden kann.“(Ripfel/Wiegand 1988: 496). 
without exception: 'Several of the more recent empirical works can hardly be taken seriously, since they are neither theoretically sound nor methodologically well thought-out.' ["Mehrere der neueren empirischen Arbeiten sind kaum ernst zu nehmen, da sie weder theoretisch fundiert noch methodologisch durchdacht sind"] (Wiegand 2008: 2). For example, in studies involving questionnaires, only a very few researchers make the questionnaires they have used available. This is necessary, however, in order to be able to fully evaluate how particular answers have come about, for instance, when the order and interaction of the individual questions, or the type of scales and how they are verbalized may influence the response behaviour. Bergenholtz, too, criticizes "the totally unscientific and actually almost meaningless surveys, in which the respondents were not selected in accordance with the principles of social science" (Bergenholtz 2011: 32).

In principle, research literature on dictionary use can be divided into two groups - individual studies and reviews. The latter summarize the results of several individual studies, but up until now, there have been no overviews which are concerned only with research into the use of electronic dictionaries. Welker (2006 a and 2010), however, is at least one work which has a chapter devoted to research into the use of electronic dictionaries. The individual studies often have sections which summarize the research which has been carried out up to that point, from the viewpoint of the particular research topic in hand.

In the following section, the most important individual studies on digital dictionaries are presented in chronological order. The preceding boxes provide a short summary. Publications in which the author only documents the observation of his/her own user behaviour are excluded, since these do not belong to the field of research into dictionary use, but rather to the field of critical dictionary research (see section 2). Examples of such accounts are Heuberger (2000), Winkler (2001 a), Tribble (2003), and Krajka (2004), who evaluate dictionaries on CD-ROM, Drápela (2005), Chiari (2006), Simonsen (2007), and Mann (2010), who assess online dictionaries, and Tono (2009), who deals with PEDs. 


\subsection{Important individual studies}

\subsubsection{Leffa (1993)}

\begin{tabular}{ll}
\hline Type of investigation: & Observation/test \\
\hline Subjects: & $\begin{array}{l}20 \text { students of English as a foreign language } \\
\text { and } 51 \text { mathematics students }\end{array}$ \\
\hline Subject matter: & $\begin{array}{l}\text { Comparison between a printed and an elec- } \\
\text { tronic dictionary when used for translation, } \\
\text { attitudes towards the electronic dictionary }\end{array}$ \\
\hline Result: & $\begin{array}{l}\text { Participants translated texts better and more } \\
\text { quickly with the electronic dictionary, partic- } \\
\text { ipants had a positive attitude towards the } \\
\text { electronic dictionary }\end{array}$ \\
\hline
\end{tabular}

Vilson Leffa, who was conducting research into the use of electronic dictionaries as early as the beginning of the 1990 s, can be considered to be a pioneer in this field. In his essay "Using an Electronic Dictionary to Understand Foreign Language Texts" he summarizes the results of several of his works, in which he compares printed and electronic bilingual dictionaries when used for reading texts. For this study, 20 students of English as a foreign language in the first semester of lower middle school translated several sections from newspapers into their native language, Portuguese, using either a printed or an electronic dictionary (cf. Leffa 1993: $23 \mathrm{ff}$.). The individual sections were divided equally between the two different types of dictionary. The results of the test show that the use of an electronic dictionary led, on average, to a $38 \%$ better understanding of the text, and that weaker students benefitted most from using an electronic dictionary (cf. Leffa 1993: 25 f.). Furthermore, with the electronic dictionary, the texts were translated not only better, but also more quickly: using the printed dictionary, the students needed on average 17.34 minutes to translate a text, while using the electronic dictionary, it was only 12.5 minutes (cf. Leffa 1993: 26). In addition to this, Leffa investigated attitudes towards the electronic dictionary. For this, 51 mathematics students worked on text comprehension exercises, translating the texts with the help of an electronic dictionary. The opinions of the students on the electronic dictionary turned out to be very positive, with more than $80 \%$ finding it more helpful than traditional printed dictionaries. The speed of the electronic dictionary and the fact that it was easy to use were particularly emphasized (cf. Leffa 1993: 26 f.). 


\section{Aust/Kelley/Roby (1993)}

\begin{tabular}{ll}
\hline Type of investigation: & Observation/test \\
\hline Subjects: & $\mathbf{8 0 ~ s t u d e n t s ~ o f ~ S p a n i s h ~ a s ~ a ~ f o r e i g n ~ l a n g u a g e ~}$ \\
\hline Subject matter: & $\begin{array}{l}\text { Comparison between printed and electronic, } \\
\text { monolingual and bilingual dictionaries, } \\
\text { attitudes towards electronic dictionaries }\end{array}$ \\
\hline Result: & $\begin{array}{l}\text { Participants looked up more words and more } \\
\text { quickly with the electronic dictionary, partic- } \\
\text { ipants had a positive attitude towards the } \\
\text { electronic dictionary }\end{array}$ \\
\hline
\end{tabular}

Aust/Kelley/Roby also compare electronic dictionaries and printed dictionaries. With 80 students of Spanish as a foreign language, they investigated the influence that the dictionary medium (electronic or printed) as well as the number of languages a dictionary contains (monolingual or bilingual) has on the process of looking up words. The results can be summarized as follows: the groups which used electronic dictionaries looked up more than twice as many words as the groups with the printed dictionaries, and were 20\% faster at looking up words. (Roby 1999: $97 \mathrm{f}$ presents the same results.) The groups with the bilingual dictionaries consulted their dictionaries more than $25 \%$ more often than the groups with the monolingual dictionaries and needed around 20\% less time. The participants could therefore look words up more quickly in electronic and bilingual dictionaries than in printed or monolingual dictionaries. There were no differences in comprehension between the electronic and printed dictionaries or between the bilingual and monolingual dictionaries. The participants in Aust et al. were likewise very positive about electronic dictionaries, again with particular emphasis on the fact that they are easy and quick to use.

\subsubsection{Laufer/Hill (2000)}

\begin{tabular}{ll}
\hline Type of investigation: & Observation (log files) \\
\hline Subjects: & $\begin{array}{l}72 \text { students of English as a foreign language } \\
\text { (Israel and China) }\end{array}$ \\
\hline Subject matter: & $\begin{array}{l}\text { Which types of information are looked up, } \\
\text { vocabulary retention }\end{array}$ \\
\hline Result: & $\begin{array}{l}\text { Participant groups preferred different types } \\
\text { of information, no correlation between how } \\
\text { often a word was looked up and how well it } \\
\text { was retained }\end{array}$ \\
\hline
\end{tabular}

In 2000, Laufer/Hill tested the comprehension of unknown vocabulary through the use of logfile analysis. The focal point of the investigation was precisely what infor- 
mation is looked up and how unknown vocabulary is retained. The following aspects of investigation using log files are named as advantages:

"Some studies report that electronic or paper dictionaries were available to the class. This, in itself, however, does not necessarily mean that learners looked up the words the researcher assumed would be looked up. If a study does not provide log files which record what learners are doing during the reading task, there is no evidence that they indeed are looking up unknown words, rather than guessing or ignoring them. Nor do we have the information about the number of times they return to a specific word during the reading task." (Laufer/Hill 2000: 59)

If different types of information, such as translation equivalents, definitions or grammatical information, are made available to participants for the task, then it is also possible to check which information is preferred when looking up which words and what effect this has on retention rates. Laufer/Hill tested 12 low-frequency words on 72 advanced students of English as a foreign language from Haifa and Hong Kong, words which were unknown to the students. For this, they used the Words in your ear programme, which logs which information is looked up about which words and how frequently (cf. Laufer/Hill 2000: $61 \mathrm{ff}$.). Afterwards, the vocabulary retention rate of the students was checked by means of a vocabulary test which they were not told about in advance. The Israeli students could remember the meanings of four words on average, while the Chinese students could remember seven. The best retention rates were obtained by the students from Haifa when they looked up both native-language and foreign-language information about the word they were looking for. The Hong Kong students obtained the best scores when looking up words in the foreign language. No correlation could be found between how frequently words were looked up and how well they were retained (cf. Laufer/Hill 2000: $65 \mathrm{ff}$.). Again in Laufer/Hill, emphasis was placed on the ease and speed of using electronic dictionaries as advantages of the medium.

\subsubsection{Laufer (2000)}

\begin{tabular}{ll}
\hline Type of investigation: & Observation (log files) \\
\hline Subjects: & 55 students of English as a foreign language \\
\hline Subject matter: & $\begin{array}{l}\text { Comparison between a printed and an elec- } \\
\text { tronic dictionary, what information is looked } \\
\text { up in the electronic dictionary, vocabulary } \\
\text { retention }\end{array}$ \\
\hline Result: & $\begin{array}{l}\text { Participants with the electronic dictionary } \\
\text { achieved better vocabulary retention rates, } \\
\text { better long-term retention rates were } \\
\text { achieved by participants who used several } \\
\text { types of information when looking up words }\end{array}$ \\
\hline
\end{tabular}


In terms of the structure of the experiment, Laufer/Hill is similar to Laufer's study: two parallel groups of participants of a total of 55 students of English as a foreign language looked up unknown vocabulary to complete a text comprehension exercise using an electronic or a printed dictionary. The types of information they relied on (translation, English definition, example of use) were logged in the electronic dictionary. Vocabulary retention was checked by means of tests which the participants were not told about in advance, one immediately after the experiment, and a second two weeks later. In both retention tests the group with the electronic dictionary achieved better results. As possible reasons for these results, Laufer cites firstly the more striking appearance of the electronic information, and secondly the closer involvement of the users when looking for the meanings of the words. In contrast to other investigations, Laufer's study finds differences in long-term vocabulary retention rates, which are connected to the type of information the participants looked up:

"The immediate recall does not seem to be significantly affected by the type of information selected even though the scores are higher for words looked up in both languages. The long term recall scores, however, are significantly higher when a combination of translation, definition and example is selected." (Laufer 2000: 852)

Possible reasons given for this are both the more extensive semantic encoding as well as the longer attentiveness of the participants (cf. Laufer 2000: $852 \mathrm{f}$.).

\subsubsection{Nesi (2000)}

\begin{tabular}{ll}
\hline Type of investigation: & Observation (log files) \\
\hline Subjects: & 29 students of English as a foreign language \\
\hline Subject matter: & $\begin{array}{l}\text { Comparison between a printed and an elec- } \\
\text { tronic dictionary }\end{array}$ \\
\hline Result: & $\begin{array}{l}\text { Participants with an electronic dictionary } \\
\text { looked up more words, found looking up } \\
\text { words easier and were more satisfied with } \\
\text { the results }\end{array}$ \\
\hline
\end{tabular}

Like Aust/Kelley/Roby and Laufer, Nesi also compares electronic and printed dictionaries. For this, 29 students of English as a foreign language read Englishlanguage texts, either with a printed dictionary or with its equivalent on CD-ROM. Every time they looked up a word, the students documented this along with an assessment of how easily they had found the required information and how satisfied they were with it. Some of the results are astonishing: 
"Although the dictionary definitions on screen and in print were the same, subjects looked up more words when using the CD-ROM, found look-up significantly easier, and were significantly more satisfied with the results." (Nesi 2000 b: 111)

These results correspond with those of the earlier studies outlined above.

\subsubsection{Corris/Manning/Poetsch/Simpson (2000)}

\begin{tabular}{ll}
\hline Type of investigation: & Observation/test \\
\hline Subjects: & 76 speakers of Aboriginal languages \\
\hline Subject matter: & $\begin{array}{l}\text { Comparison between a printed and an elec- } \\
\text { tronic dictionary }\end{array}$ \\
\hline Result: & $\begin{array}{l}\text { Participants with an electronic dictionary had } \\
\text { fewer problems when looking up words }\end{array}$ \\
\hline
\end{tabular}

In the proceedings from Euralex 2000, two more articles, in addition to Laufer, are devoted to the topic of research into dictionary use. Corris et al. examine the use and user-friendliness of multilingual dictionaries of Aboriginal languages by observing 76 speakers using dictionaries and giving them exercises on dictionary use. Here also, with regards to the results relating to electronic dictionaries, the comparison with printed dictionaries was at the forefront: problems caused by alphabetical access or the word list played a much greater role in the printed dictionary than in the electronic dictionary (cf. Corris et al. 2000: $175 \mathrm{f}$.). The same applied when looking for inflected forms, which, as it was possible to be automatically forwarded to the basic form, was more successful in the electronic dictionary than in the printed dictionary. According to Corris et al., other advantages of electronic dictionaries are the integration of sound recordings for information on pronunciation and the variable font size (cf. Corris et al. 2000: $176 \mathrm{f}$.). Again, in this investigation, the participants were very receptive to the electronic dictionary.

\subsubsection{Tono (2000)}

\begin{tabular}{ll}
\hline Type of investigation: & Observation/test \\
\hline Subjects: & 5 students of English as a foreign language \\
\hline Subject matter: & $\begin{array}{l}\text { Comparison between printed and electronic } \\
\text { dictionaries as well as different types of } \\
\end{array}$ \\
& interface \\
\hline Result: & $\begin{array}{l}\text { Participants with an electronic dictionary } \\
\text { looked up words more quickly, and most } \\
\\
\text { quickly with a parallel bilingual interface }\end{array}$ \\
\hline
\end{tabular}


Tono addresses how easy it is to look up words: are there differences between electronic and printed dictionaries, between different electronic interfaces (traditional, parallel bilingual and step-form), between different types of task and when a user becomes accustomed to a particular interface? His participants were five Japanese students of English as a foreign language, who were filmed whilst working on the tasks they had been given. The extremely low number of participants is problematic when drawing general conclusions. Tono's study confirms that electronic dictionaries allow quicker access than printed dictionaries. The quickest access for the participants was via the parallel bilingual interface (cf. Tono 2000: $856 \mathrm{ff}$.).

\subsubsection{Lemnitzer (2001)}

\begin{tabular}{ll}
\hline Type of investigation: & Observation (log files) \\
\hline Subjects: & 149,830 accesses \\
\hline Subject matter: & $\begin{array}{l}\text { Examination of why words are unsuccessfully } \\
\text { looked up }\end{array}$ \\
\hline Result: & $\begin{array}{l}\text { Common reasons for unsuccessful searches } \\
\text { were spelling mistakes, gaps in the lemmata, } \\
\text { problems in the choice of basic form/lemma } \\
\text { and choosing the wrong dictionary }\end{array}$ \\
\hline
\end{tabular}

Lemnitzer examined the $\log$ files of a total of four bilingual electronic dictionaries (English-German, German-English, French-German and German-French) for a total period of 28 months. He was interested above all in the reasons why looking up words goes wrong. The investigation period was divided into two phases. In the first phase, $62 \%$ of all searches were unsuccessful. The most common reasons for this were misspelling the search word, gaps in lemmata in the dictionary, problems in the choice of basic form/lemma or choosing the wrong dictionary (cf. Lemnitzer 2001: 250). This knowledge was used before the second phase of the investigation to make alterations to the interface of the dictionaries. For instance, the search function was made more able to tolerate mistakes and it was emphasized more clearly that a dictionary was to be chosen before the search. This had a positive effect on the success of the searches, which were now successful in almost $46 \%$ of cases. 
Winkler (2001 a)

\begin{tabular}{ll}
\hline Type of investigation: & $\begin{array}{l}\text { Questionnaire, test, observation } \\
\text { (commentaries) }\end{array}$ \\
\hline Subjects: & 30 students of English as a foreign language \\
\hline Subject matter: & $\begin{array}{l}\text { Comparison between a printed dictionary and } \\
\text { a dictionary on CD-ROM }\end{array}$ \\
\hline Result: & $\begin{array}{l}\text { With the printed dictionary and the dictionary } \\
\text { on CD-ROM, sometimes different skills were } \\
\text { needed, different problems arose }\end{array}$ \\
\hline
\end{tabular}

In her study, Winkler also compares a printed and an electronic dictionary. 30 students of English as a foreign language first of all completed a questionnaire about the ownership and use of their dictionaries. Afterwards, they had to write a short text on screen, for which they had the $O A L D$ at their disposal, first as a book and later on CD-ROM. Furthermore, the students were encouraged to think aloud during the writing task, and these remarks were recorded. In addition, observers noted details about individual searches for words. In the evaluation, Winkler concentrates on the skills dictionary users must have, as well as on problems which arose while the dictionaries were being used. Both the skills and the problems sometimes differ in relation to $\mathrm{CD}-\mathrm{ROM}$ or printed dictionaries. All participants agreed that searches in the CD-ROM dictionary were quicker and more comfortable than in the printed dictionary. Unfortunately, there is no evaluation of the questionnaire.

\subsubsection{Selva/Verlinde (2002)}

\begin{tabular}{ll}
\hline Type of investigation: & Observation (log files)/test \\
\hline Subjects: & 67 learners of French as a foreign language \\
\hline Subject matter: & $\begin{array}{l}\text { Investigation of how users deal with an elec- } \\
\text { tronic dictionary for learners of French }\end{array}$ \\
\hline Result: & $\begin{array}{l}\text { Users had difficulty finding information in } \\
\text { extensive word entries and long definitions }\end{array}$ \\
\hline
\end{tabular}

Within the framework of Euralex 2002, Selva/Verlinde look closely at the issue of how users of an electronic dictionary for learners of French cope with the dictionary. For this, two groups of Dutch-speaking students with 40 and 27 participants respectively completed four different tasks, and their actions were logged. The tasks consisted of assigning the correct individual meaning of a word from its dictionary entry in a text comprehension exercise, translating into the foreign language, looking for appropriate synonyms and coping with the actant schema. Problems arose for the users mainly when trying to find information in the word entries of polysemous head words and in long definitions (cf. Selva/Verlinde 2002: $774 \mathrm{ff}$.). 


\subsubsection{Ernst-Martins (2003)}

\begin{tabular}{ll}
\hline Type of investigation: & Observation/test \\
\hline Subjects: & $\mathbf{1 5}$ students of Spanish as a foreign language \\
\hline Subject matter: & Text comprehension using different types of \\
& dictionary (monolingual, bilingual, online) \\
\hline Result: & Online dictionary supported text comprehen- \\
& sion best, it also allowed the quickest access \\
\hline
\end{tabular}

In her dissertation, Ernst-Martins starts from the hypothesis that a bilingual online dictionary, which is linked to a text, will increase the understanding of this text in comparison with other dictionaries. To test this hypothesis, a total of 15 students of Spanish as a foreign language, divided into three groups of five students, translated three shorter texts from Spanish into Portuguese, either with a monolingual printed dictionary, a bilingual printed dictionary or an online dictionary linked to the text. The dictionaries were swapped round so that every group used different dictionaries for all the texts, and every text was translated with all the dictionaries. The online dictionary linked to the text came off best regardless of how difficult the text was, and the tasks set were completed the most quickly with it as well.

\subsubsection{Hill/Laufer (2003)}

\begin{tabular}{ll}
\hline Type of investigation: & Observation (log files) \\
\hline Subjects: & 96 students of English as a foreign language \\
\hline Subject matter: & $\begin{array}{l}\text { Influence of the type of task on vocabulary } \\
\text { retention }\end{array}$ \\
\hline Result: & $\begin{array}{l}\text { Frequently looking up words in the dictionary } \\
\text { had a positive influence on vocabulary learn- } \\
\end{array}$ \\
& ing \\
\hline
\end{tabular}

Hill/Laufer once again address vocabulary retention. They investigated how different types of tasks influence vocabulary learning. 96 students of English as a foreign language from Hong Kong read a text containing 12 unknown words and worked on the unknown vocabulary in various tasks: yes-no comprehension questions or multiple choice comprehension questions (based on the form or meaning of the word). For each unknown word, the participants could learn about the pronunciation, the English and Chinese meaning in addition to supplementary information. A computer programme logged all the participants' activities as well as how long they took. Immediately after the tasks, a vocabulary test which the participants had not been told about in advance was set, and then a second unannounced test was set a week later. The participants who had only answered yes-no comprehension questions on the unknown vocabulary fared worst in both retention tests. There were no 
significant differences in the time needed to complete the tasks. For the task which involved answering multiple choice questions about the meaning of the word, the participants used the most search options, with the focus on translation into Chinese. With the other two types of task, on the other hand, the English explanation was used the most. Hill/Laufer infer from the results of the study that frequently looking up words in a dictionary has a positive influence on vocabulary retention.

\subsubsection{De Schryver/Joffe (2004)}

\begin{tabular}{ll}
\hline Type of investigation: & Observation (log files) \\
\hline Subjects: & 2,530 users, 21,337 accesses \\
\hline Subject matter: & $\begin{array}{l}\text { Investigation of how users deal with a bilin- } \\
\text { gual internet dictionary }\end{array}$ \\
\hline Result: & $\begin{array}{l}\text { Users mostly looked up frequent words and } \\
\text { taboo vocabulary }\end{array}$ \\
\hline
\end{tabular}

De Schryver/Joffe also work with the logging method, albeit with the difference that their $\log$ files arise directly from the normal use of an internet dictionary rather than within the context of a specially designed test. This has the crucial advantage that all the actions of the users are recorded in natural dictionary usage situations. De Schryver/Joffe call this procedure Fuzzy SF (Fuzzy Simultaneous Feedback):

"In Fuzzy SF, traditional means for gathering feedback such as participant observation or questionnaires are replaced with the computational tracking of all actions in an electronic dictionary." (De Schryver/Joffe 2004: 188)

As well as the analysis of the $\log$ files, this article is concerned with the evaluation of comments which are sent via the contact form of the internet dictionary. The internet dictionary is a bilingual Sesotho sa Leboa-English dictionary, the user actions of which have been logged since its inception via user IDs. The article analyzes the $\log$ files from the first six months after the dictionary was activated on the internet. The 2,530 users looked up words a total of 21,337 times, which gives an average of 8.4 searches per user (cf. De Schryver/Joffe 2004: 189). 65\% of the searches were from English to Sesotho sa Leboa. Comparisons between the most frequently looked up words in Sesotho sa Leboa und the 1,000 most frequent words in that language show, "that genuine frequent words are looked up on the one hand, and then those words that only mother-tongue speakers know but, as they are taboo, never pronounce in public" (De Schryver/Joffe 2004: 190; their italics, cf. also Lemnitzer 2001: $251 \mathrm{f}$.). The $\log$ files of individual users allow conclusions to be drawn about their individual search strategies: for example, words from the same semantic field are often looked up after each other. Users switch to semantically similar words when- 
ever typing errors mean that the word they originally searched for is not successfully looked up.

\subsubsection{Bergenholtz/Johnsen (2005)}

\begin{tabular}{ll}
\hline Type of investigation: & Observations (log files) \\
\hline Subjects: & 2,239 accesses a day \\
\hline Subject matter: & Investigation of how users deal with a bilin- \\
& gual internet dictionary \\
\hline Result: & Users often looked up taboo vocabulary, and \\
& also many non-lemmatized words \\
\hline
\end{tabular}

Bergenholtz/Johnsen likewise the use log file analysis method as a "tool for improving internet dictionaries" (Bergenholtz/Johnsen 2005: 117). Like De Schryver/Joffe, Bergenholtz/Johnsen also devote a short section to users' emails (cf. Bergenholtz/Johnsen 2005: 140). The dictionary analysed is the monolingual Danish dictionary Den Danske Netordbog, which is accessed on average 2,239 times a day. Almost $20 \%$ of the searches were for words which are not lemmatized in the dictionary. Most searches $(84 \%)$ were for the lemma itself. The option of searching for the beginning of a lemma (just under $8 \%$ ), a sequence of letters contained in it (over $6 \%$ ) or the end of a lemma (just under $2 \%$ ) was taken advantage of much less often. Bergenholtz/Johnsen also note - just like De Schryver/Joffe a year earlier - the relatively high proportion of sexual vocabulary in the searches. Particular problems with searches arose through passive and imperative forms of verbs, the misspelling of words (influenced by pronunciation), mistakenly writing words as separate words or as one word, incorrect word forms, differences in morphological joins or through gaps in the lemmata (particularly common with terms from the specialist areas of computer science, finance, law and medicine) (cf. Bergenholtz/Johnsen 2005: $127 \mathrm{ff}$.). Bergenholtz/Johnsen estimate the proportion of lemmata searched for in the logged time period to be a good third of the total stock of lemmata (cf. Bergenholtz/Johnsen 2005: 139). 


\subsubsection{Haß (2005)}

\begin{tabular}{ll}
\hline Type of investigation: & Survey (questionnaire) \\
\hline Subjects: & 427 students and academics \\
\hline Subject matter: & $\begin{array}{l}\text { Investigation of the labelling of the buttons of } \\
\text { a monolingual internet dictionary }\end{array}$ \\
\hline Result: & $\begin{array}{l}\text { Participants for the most part favoured sev- } \\
\text { eral labels }\end{array}$ \\
\hline
\end{tabular}

The first study of electronic dictionary use known to us which uses a questionnaire is $\mathrm{Haß}$ (2005). 82\% of the 427 participants consisted of students und 11\% consisted of academics from the Institute for German Language as well as Germanists from abroad. $71 \%$ of those questioned were native speakers. The aim of the study was to investigate the language of the user interface of the monolingual German internet dictionary elexiko, which at the time of the investigation was still called Wissen über Wörter. For this, the participants were put into possible dictionary use situations. From this situation, they had to judge different ways of labelling the individual buttons in terms of how easy they were to understand, for instance in relation to the meaning, connotations, origin or pragmatics of a word. Since the survey produced no clear results relating to this, but rather several options obtained similar levels of agreement, the author argues for a double labelling of the buttons as well as for 'detailed paraphrases, i.e. a kind of glossary of the lexicographical designations, which is readily accessible to the user' ['ausführliche Paraphrasierungen [...], d. h. eine Art Glossar der lexikografischen Benennungen, nach dem die Nutzer nicht lange suchen müssen"] (Haß 2005: 39).

\subsubsection{Sánchez Ramos (2005)}

\begin{tabular}{ll}
\hline Type of investigation: & Questionnaire \\
\hline Subjects: & 98 translation students \\
\hline Subject matter: & $\begin{array}{l}\text { Requirements and habits of translation stu- } \\
\text { dents when using dictionaries }\end{array}$ \\
\hline Result: & $\begin{array}{l}\text { Participants were not familiar with using } \\
\text { electronic dictionaries }\end{array}$ \\
\hline
\end{tabular}

Sánchez Ramos conducted research into the dictionary use of 98 translation students, through the use of a questionnaire. The second part of the questionnaire was concerned with electronic reference works. In 2005, the majority of the participants were not familiar with dictionaries on CD-ROM, be these monolingual Spanish or English dictionaries or bilingual dictionaries. Likewise, most of those questioned did not know of any monolingual English online dictionaries. On the other hand, monolingual Spanish as well as bilingual online dictionaries were known to the 
majority. The participants stressed speed of access as well as accessibility and usefulness as advantages of electronic dictionaries, but felt that their own lack of skills in using electronic dictionaries was a disadvantage.

\subsubsection{De Schryver/Joffe/Joffe/Hillewaert (2006)}

\begin{tabular}{ll}
\hline Type of investigation: & Observation (log files) \\
\hline Subjects: & approximately half a million accesses \\
\hline Subject matter: & $\begin{array}{l}\text { Investigation of how users deal with a bilin- } \\
\text { gual internet dictionary }\end{array}$ \\
\hline Result: & Users mostly looked up frequent words \\
\hline
\end{tabular}

De Schryver/Joffe/Joffe/Hillewaert also choose the same procedure as De Schryver/Joffe for a different internet dictionary, the Swahili-English dictionary written by Hillewaert/Joffe/De Schryver. They observe:

"Log files attached to such dictionaries clearly show that users increasingly assume that electronic dictionaries behave like Web search engines such as Google, and type in concatenations of keywords, combinations and phrases surrounded by quotes, entire sentences, and even dump full paragraphs (lifted from other sources) into the search field. In addition to that, an increasing number of people do not care about spelling, even type in SMS-like words and smileys, and search for a variety of languages other than the one(s) the dictionary is treating." (De Schryver et al. 2006: 71 ; their italics)

Users of online dictionaries therefore search for more than just words. De Schryver et al. project from the number of searches and from the dictionary content, "that all dictionary data will indeed be seen over time" (De Schryver et al. 2006: 71; their italics). Based on the dictionary of Sesotho sa Leboa-English, they claim also for this dictionary: "It is and remains true that the top few thousand words of a language are also those that users most frequently look up, but the real question one wishes to answer is what happens beyond that point" (De Schryver et al. 2006: 74). For this, they examined the extent to which there were correlations between the order in which words are looked up and how often they appear in the corpus. The result of their investigation is,

"that there is indeed some minor correlation between corpus ranks and actual dictionary lookup ranks for the first few thousand words [...], but beyond that point there simply is no correlation whatsoever. This is a hugely important - albeit shocking - revelation, as it means that it is simply impossible to 'predict' which words will be of interest to the dictionary user." (De Schryver et al. 2006: 78)

As a consequence of these results, the corpus should only be used "as a guidance" (De Schryver et al. 2006: 78) when selecting and ordering which lemmata in a dictionary to work on. 


\subsubsection{Laufer/Levitzky-Aviad (2006)}

\begin{tabular}{ll}
\hline Type of investigation: & Test, observation (log files) \\
\hline Subjects: & 75 students \\
\hline Subject matter: & $\begin{array}{l}\text { Comparison between four different dictionar- } \\
\text { ies, including the printed and digital versions } \\
\text { of the Bilingual Dictionary Plus }\end{array}$ \\
\hline Result: & $\begin{array}{l}\text { Bilingual Dictionary Plus was advantageous } \\
\text { irrespective of medium }\end{array}$ \\
\hline
\end{tabular}

The focus of the Laufer/Levitzky-Aviad study is on the evaluation of a HebrewEnglish bilingual dictionary with supplementary information (the so-called Bilingual Dictionary Plus). 75 students translated 36 sentences from Hebrew into English, but the dictionary being used was changed every nine sentences, so that a total of four dictionaries were used. In the context of electronic dictionaries, the comparison between the printed and digital versions of the Bilingual Dictionary Plus is of interest. Irrespective of the medium, the Bilingual Dictionary Plus proved itself against the normal bilingual and bilingualized dictionary. In the electronic version, most participants looked up the translation with definitions and examples or just the translation.

\subsubsection{Boonmoh/Nesi (2008)}

\begin{tabular}{ll}
\hline Type of investigation: & Survey (questionnaire) \\
\hline Subjects: & 30 high school teachers and 1,211 students \\
\hline Subject matter: & Knowledge and use of PEDs \\
\hline Result: & $\begin{array}{l}\text { Teachers preferred and recommended mono- } \\
\text { lingual printed dictionaries, students fa- } \\
\text { voured bilingual dictionaries and PEDs }\end{array}$ \\
\hline
\end{tabular}

The aim of Boonmoh/Nesi's study was to examine the use and knowledge of PEDs. For this, 30 high school teachers and 1,211 students in Thailand, who were teaching or learning English, were questioned by means of questionnaires (cf. Boonmoh/Nesi 2008). Of the 30 high school teachers, 29 owned at least one monolingual English dictionary in print form, and 22 owned one on CD-ROM. 11 teachers indicated that they used bilingual online dictionaries, and nine used monolingual online dictionaries. Only four used a PED. The teaching staff had hardly any knowledge of the lexicographical content of PEDs, with the exception of the few teachers who used them. By and large, the teachers preferred printed dictionaries, regardless of the type of task (text reception or text production). The use of electronic dictionaries also seemed, however, to be linked to working at a computer. The majority of the high school teachers disapproved of the use of PEDs, with almost all encouraging 
their students to use monolingual dictionaries. $95 \%$ of the students questioned owned at least one dictionary - of these, $82 \%$ had a monolingual printed dictionary, $45 \%$ a bilingual printed dictionary and $40 \%$ a PED. The students liked using bilingual printed dictionaries and PEDs the most. By contrast, they did not like using monolingual printed dictionaries: "there was a great mismatch between the number of respondents who stated that they owned a monolingual print dictionary (1149) and the number who stated that they normally used one (46 for reading, and 102 for writing)" (Boonmoh/Nesi 2008).

\subsubsection{Petrylaite/Vežyte/Vaškeliene (2008)}

\begin{tabular}{ll}
\hline Type of investigation: & Survey (questionnaire) \\
\hline Subjects: & 88 IT students \\
\hline Subject matter: & $\begin{array}{l}\text { Comparison of printed and electronic, mono- } \\
\text { lingual and bilingual dictionaries }\end{array}$ \\
\hline Result: & $\begin{array}{l}\text { Participants used monolingual electronic } \\
\text { dictionaries almost as frequently as bilin- } \\
\\
\text { gual, participants looked words up more } \\
\text { frequently with the electronic dictionary }\end{array}$ \\
\hline
\end{tabular}

Petrylaite/Vežyte/Vaškeliene also carried out a study using questionnaires, which, amongst other things, compared printed and electronic dictionaries. The 88 participants were Lithuanian IT students, who were learning English for specific purposes. The following results are of significance in the context of electronic dictionaries. In the case of printed dictionaries, the participants clearly and exclusively preferred the bilingual ones. However, when it came to electronic dictionaries, they used monolingual dictionaries in the target language almost as often. On the whole, the participants used electronic dictionaries rather more frequently than printed dictionaries. Speed of access, ease of use, variety and the fact that they are free of charge were named as the main advantages (cf. Petrylaite/Vežyte/Vaškeliene 2008: $80)$. 


\section{Lew/Doroszewska (2009)}

\begin{tabular}{ll}
\hline Type of investigation: & Observation (log files) \\
\hline Subjects: & 56 learners of English \\
\hline Subject matter: & $\begin{array}{l}\text { Which information is looked up, vocabulary } \\
\text { retention, influence of animated pictures }\end{array}$ \\
\hline Result: & Participant groups preferred translation \\
& information, no correlation between how \\
& often words were looked up and retention \\
& rates, consulting only animated pictures led \\
& to the worst retention rates \\
\hline
\end{tabular}

Lew/Doroszewska expanded on Laufer/Hill's (2000) study and carried it out on 56 Polish learners of English in upper school (for methodology, see section 3.2.3). The expansion sought to establish the extent to which consulting animated pictures during text reception influences the learning of these words. By far the type of information most frequently chosen by the participants (two-thirds of the searches) was the Polish translation. The remaining third was divided between the animated pictures (18\%), the English definition (just under 12\%) and the examples (just under $3 \%$ ). The data from Lew/Doroszewska confirm that there is no statistically significant correlation between how often a word is looked up and retention rate. The highest retention rate was achieved with the words for which both the Polish translation and the English definition were consulted. The participants remembered least well the words for which only the animated pictures were consulted.

\subsubsection{Simonsen (2009)}

\begin{tabular}{ll}
\hline Type of investigation: & $\begin{array}{l}\text { Observation (eye-tracking and thinking } \\
\text { aloud) }\end{array}$ \\
\hline Subjects: & 5 participants \\
\hline Subject matter: & $\begin{array}{l}\text { Preferences for different ways of presenting } \\
\text { data }\end{array}$ \\
\hline Result: & $\begin{array}{l}\text { The preferred type of data presentation was } \\
\text { determined by the type of task }\end{array}$ \\
\hline
\end{tabular}

In Simonsen's eye-tracking study, a total of just five participants had to carry out different searches in an internet dictionary, the contents of which were available in two versions, with a horizontal and a vertical data presentation. At the same time, the participants said their thoughts aloud. Which version of the data presentation the participants preferred depended on the type of task they were carrying out: the horizontal organization of the data lent itself to cognitive dictionary functions, while the vertical one lent itself to communicative functions (cf. also Simonsen 2011: 78). 


\subsubsection{Chen (2010)}

\begin{tabular}{ll}
\hline Type of investigation: & Test and survey (questionnaire) \\
\hline Subjects: & 85 Chinese students of English (main subject) \\
\hline Subject matter: & Comparison of the use of PEDs and printed \\
& dictionaries and their effectiveness in vocab- \\
& ulary learning \\
\hline Result: & No significant differences between the two \\
& types of dictionary; only the time taken to \\
& complete tasks was significantly shorter with \\
& PEDs \\
\hline
\end{tabular}

The investigation carried out by Chen aimed to compare the perception and use of PEDs and printed dictionaries as well as their respective effectiveness in vocabulary acquisition. His participants were 85 Chinese advanced learners of English who were studying English as a main subject and who took part completely in the test. 61 questionnaires could later be collected from these students. The printed dictionary at their disposal was the bilingualised Oxford Advanced Learner's English-Chinese Dictionary, while on the PEDs, the participants were likewise to use bilingualized English-Chinese dictionaries. The participants were randomly assigned to groups which were to use either the printed dictionary or the PEDs. The vocabulary test, with ten low-frequency words unknown to the participants, consisted of both receptive and productive elements, and was followed by two retention tests which the participants had not been told about in advance. Although the participants were equally successful in both the receptive and productive tasks, regardless of the type of dictionary they used, the group with the PEDs completed the tasks significantly more quickly. In the retention tests which followed, however, there were no significant differences between the two groups. The results of the questionnaires showed that the students used PEDs considerably more often than printed dictionaries. PEDs were used mostly when reading, while printed dictionaries were used when completing exercises. The information areas other than the explanation of meaning were consulted more often in the printed dictionaries than in the PEDs. The three most frequently searched-for areas in the PEDs were semantic information, pronunciation and collocations, while in the printed dictionaries it was semantic information, examples and collocations. In the case of the least used areas of information information about style, pragmatics and derived or related words - there were no differences between the types of dictionary. When using PEDs, the students indicated more frequently that in the case of polysemous entries, they decided on one of the first versions. Core information was noted more frequently after using printed dictionaries. Just under half of the participants thought that printed dictionaries were more effective for learning vocabulary. PEDs were judged to be most useful for reading, printed dictionaries for translating and writing. On the whole, the partici- 
pants were more satisfied with the use of printed dictionaries, as they considered the information available in these to be more comprehensive.

\subsubsection{Dziemianko (2010)}

\begin{tabular}{ll}
\hline Type of investigation: & Test \\
\hline Subjects: & 64 Polish students of English \\
\hline Subject matter: & Testing the usefulness of an electronic and a \\
& printed monolingual learners' dictionary in \\
& production and reception, as well as in vo- \\
& cabulary learning \\
\hline Result: & Online version fared better in productive and \\
& receptive tasks as well as in retention results \\
\hline
\end{tabular}

Dziemianko pursues a similar aim in her study as Chen (2010): she compares the usefulness of a monolingual English dictionary in printed and electronic form in productive and receptive tasks, and investigates what effect the form of a dictionary has on vocabulary retention (meaning and collocations). Her test dictionary was the Collins COBUILD Advanced Dictionary as a printed dictionary and an online dictionary, and her participants were 64 intermediate and advanced Polish students of English as a foreign language. In the receptive part, the participants had to explain the meaning of nine unknown words (in their native language of Polish or in English), and in the productive part, they had to complete sentences with prepositions missing from collocations. Two weeks later, the students took a test which they did not know about in advance, which tested their vocabulary retention. Dziemianko's test showed that the group of participants with the online dictionary performed significantly better in both the productive as well as the receptive tasks than the group which used the printed dictionary. The same also applied to learning (meaning and collocation), whereby on the whole, the participants could remember the meanings of the words better than the collocations.

\subsubsection{Bank (2010)}

\begin{tabular}{ll}
\hline Type of investigation: & Usability test and survey (questionnaire) \\
\hline Subjects: & 30 students \\
\hline Subject matter: & $\begin{array}{l}\text { Investigation of the fitness for use of three } \\
\text { online language facilities (Eldit, OWID and } \\
\text { the Base lexicale du français - BLF) }\end{array}$ \\
\hline Result: & $\begin{array}{l}\text { Each of the tested facilities showed weak- } \\
\text { nesses in the area of usability, but on the } \\
\text { whole, the participants judged Eldit to be the } \\
\text { best }\end{array}$ \\
\hline
\end{tabular}


In her Master's dissertation, Bank, by means of usability tests, compares the fitness for use of different online language facilities: the German-Italian learners' dictionary Eldit, the dictionary portal $O W I D$ and the Base lexicale du français $(B L F)$. For this, 30 students completed various tasks. When looking for single-word lemmata, the participants achieved their aim most quickly using $O W I D$, while when looking for collocations, the participants managed best with Eldit. The search for synonyms of a particular word was quickest with Eldit, but the type of task set for OWID (or, more precisely, the dictionary elexiko) was a different one, for reasons not given - in this case, the participants had to find the adjectival collocations of a search word. In the associated survey, the participants judged Eldit to be the most clearly structured, and furthermore, the information they were looking for in Eldit was where they expected it to be. With both $O W I D$ and Eldit, the participants knew where they were in the dictionary at any one time, and did not land on unexpected pages. OWID was judged to be the best, as far as reversing individual actions and going back to the homepage were concerned. In terms of whether the participants were aware when new windows were being opened in the dictionary, all the dictionaries were somewhere in the middle. On the whole, the manageability of Eldit was judged to be the best. However, all three facilities tested showed weaknesses in the area of usability, which in the interests of the users should be eliminated (for further discussion cf. Bank 2012).

\subsubsection{Verlinde/Binon (2010)}

\begin{tabular}{ll}
\hline Type of investigation: & Observation (log files) \\
\hline Subjects: & 55,752 accesses \\
\hline Subject matter: & Investigation of how users manage with the \\
& Base lexical du français (BLF) \\
\hline Result: & Users were interested above all in special \\
& information (about meaning, gender and \\
& translations), frequent words were also \\
& frequently looked up \\
\hline
\end{tabular}

Using the log files of 55,752 accesses, Verlinde/Binon investigate how users use the Base lexical du français $(B L F)$, which has a modular structure, and is divided into small sections. Approximately $60 \%$ of the accesses occurred in the "Get information on" section, just under 30\% in "Get the translation of". Only $7 \%$ of the users were interested in the learning section. Of the approximately 20 information areas available in "Get information on", meaning (20\%), gender (13\%) and translation (9\%) were chosen most often. In only $11 \%$ of cases was use made of the option of displaying the whole entry according to particular information, which Verlinde/Binon see as a confirmation of the concept of the $B L F$, whereby the user is asked for the concrete reason for the search, and the presentation of the results is arranged in small 
sections accordingly. Verlinde/Binon also found a correlation between the frequency of a word in the corpus and how often it was looked up (cf. De Schryver/Joffe 2004).

\subsubsection{Boonmoh (2011)}

\begin{tabular}{ll}
\hline Type of investigation: & Survey (questionnaire) \\
\hline Subjects: & 540 first-year university students \\
\hline Subject matter: & Students' use and knowledge of PEDs \\
\hline Result: & $\begin{array}{l}\text { Many students use PEDs, but most of them } \\
\text { are not familiar with advanced functions }\end{array}$ \\
\hline
\end{tabular}

Boonmoh asked 540 first-year university students in Thailand (Faculty of Engineering, Faculty of Industrial Engineering and Faculty of Science) for their use and knowledge of PEDs. 81\% stated that they had used PEDs, 41\% (221 students) that they owned one. The two most popular PEDs were TalkingDict (106 respondents) and CyberDict (84 respondents). Out of these 190 students, 138 didn't know how many dictionaries their PED contained. Between $73 \%$ and $91 \%$ didn't know who the authors of the different dictionaries were, and 88\% didn't know which edition they had. Between 69\% and 85\% weren't aware of the special functions (cross-referral search function, wildcard search function, phrase search function, function to add new words or meanings) of the dictionaries they used. As a consequence, Boonmoh suggests some guidelines for PED purchase and training.

\subsubsection{Simonsen (2011)}

\begin{tabular}{ll}
\hline Type of investigation: & $\begin{array}{l}\text { Observation (eye-tracking) and associated } \\
\text { survey (interview) }\end{array}$ \\
\hline Subjects: & 6 professional translators \\
\hline Subject matter: & $\begin{array}{l}\text { Investigation of which points on the screen } \\
\text { are looked at and for how long }\end{array}$ \\
\hline Result: & $\begin{array}{l}\text { Lexicographical function, usage situation and } \\
\text { user profile determined which points on the } \\
\text { screen were looked at and for how long }\end{array}$ \\
\hline
\end{tabular}

Six professional translators took part in Simonsen's second eye-tracking study (which was followed by a qualitative interview). During a translation task from their native language of Danish into English, they had to look up at least five lemmata in a Danish-English frequency dictionary (Dansk-Engelske Regnskabsordbog). Because of the variable quality of the data, the results of the participants could not easily be compared, and for this reason, only three participants with three searches respec- 
tively could be considered for further analysis. The results show that the individual participants differed significantly in precisely where and for how long they looked at the screen. Simonsen concludes from this that the differences between individuals are determined by factors such as lexicographical function, usage situation and user profile.

\subsubsection{Tono (2011)}

\begin{tabular}{ll}
\hline Type of investigation: & Observation (eye-tracking) \\
\hline Subjects: & 8 students \\
\hline Subject matter: & $\begin{array}{l}\text { Investigation of the influence of various } \\
\text { elements of a dictionary entry on the process } \\
\text { of looking up words among non-native } \\
\text { speakers }\end{array}$ \\
\hline Result: & $\begin{array}{l}\text { Looking up words in a dictionary is complex } \\
\text { and is influenced by various factors (such as } \\
\text { microstructure, aids, type of information } \\
\text { being looked for and level of competence in } \\
\text { the language) }\end{array}$ \\
\hline
\end{tabular}

Tono (2011) also carries out an eye-tracking study, in order to research the process of looking words up in a dictionary among non-native speaker language learners with different levels of competence. The participants were eight Japanese students with knowledge of English as a foreign language (at least six years of study). However, for the investigation, no real digital dictionaries were used, but rather two extracts make from the Longman Dictionary of Contemporary English and fast from the Macmillan English Dictionary Online - were adapted. The participants had to find out the meaning of a word which was highlighted in red in a presented sentence, by consulting the dictionary entry on the screen. The dictionary entry had been edited in various ways, in order to evaluate the influence of different elements on the process of looking up words. The following results were recorded. The participants fared badly with the 'signposts', which highlighted the relevant individual meaning in a summary (mostly a single word) at the beginning of the entry. Furthermore, only participants with poorer competence in the language used the menus, which structured longer dictionary entries like a table of contents. Whether a piece of information in a dictionary entry was found quickly did not depend on whether the entry was monolingual or bilingual but on the type of information being looked for: if the information was at the end of a complex entry, it did not matter whether the participant was looking in a monolingual or multilingual entry. When evaluating two systems for encoding syntactic structures ( $S V O O$ and make $A B$ ), the same success rates resulted for both variants. Only the eye-tracking investigation showed that the SVOO type was not used at all and the participants succeeded in finding the right solution 
in other ways. This result demonstrates a clear advantage of the eye-tracking method, which can show not only the actual result of the search, but also the path taken to it.

\subsubsection{Dziemianko (2011)}

\begin{tabular}{ll}
\hline Type of investigation: & Test \\
\hline Subjects: & 87 Polish students of English \\
\hline Subject matter: & Testing the usefulness of an electronic and a \\
& printed monolingual learners' dictionary in \\
& production and reception, as well as in vo- \\
& cabulary learning \\
\hline Result: & $\begin{array}{l}\text { No differences between the printed and the } \\
\text { electronic form of the LDOCE5 }\end{array}$ \\
\hline
\end{tabular}

Dziemianko replicated her study on the usefulness of the COBUILD6 in printed and electronic form for the LDOCE5. The design and the materials of the study were the same as in Dziemianko (2010). 87 Polish students of English took part, 42 used the printed dictionary, 45 consulted the electronic equivalent. Dziemianko's (2010) results were not confirmed in this study, as the medium of the LDOCE5 didn't affect the students' performance in receptive and productive tasks or in retention tasks. In addition, the electronic version of the COBUILD6 performed better than the electronic version of the LDOCE5. Dziemianko suspects that "unsolicited promotional material can lose an online dictionary much of its usefulness" (Dziemianko 2011: 99).

\subsubsection{Kaneta (2011)}

\begin{tabular}{ll}
\hline Type of investigation: & Observation (eye-tracking) and test \\
\hline Subjects: & 6 students \\
\hline Subject matter: & $\begin{array}{l}\text { Differences between dictionary types (mono- } \\
\text { lingual/bilingual) and interfaces (tradition- } \\
\text { al/layered) }\end{array}$ \\
\hline Result: & $\begin{array}{l}\text { Dictionary types/interfaces do not influence } \\
\text { the success rate, but different interfaces } \\
\text { have an influence on the amount and length } \\
\text { of reference to examples }\end{array}$ \\
\hline
\end{tabular}

6 Japanese students took part in Kaneta's eye-tracking study and translation test. Kaneta wanted to find out whether different dictionary types (monolingual/bilingual) and interfaces (traditional/layered) have an influence on the success rate of consultation tasks and on the amount and length of reference to illustrative exam- 
ples. The success rate didn't differ by dictionary type or by interface. But the dictionary interface influenced both the amount and the length of reference to illustrative examples. The traditional interface led to a higher number of references, while the length of reference to the examples was longer in the layered interfaces.

\subsubsection{Law/Li (2011)}

\begin{tabular}{ll}
\hline Type of investigation: & Survey (questionnaire and interviews) \\
\hline Subjects: & 342 translation students \\
\hline Subject matter: & Use of Mobile Phone Dictionaries (MPDs): \\
& preferences and habits \\
\hline Result: & Users of MPDs need dictionary training, the \\
& functionality of MPDs should be expanded \\
\hline
\end{tabular}

Law/Li questioned 342 Hong Kong translation students about their use of Mobile Phone Dictionaries (MPDs) in translating. 66.1\% of the students (226) had installed an electronic dictionary on their mobile phone, $62.3 \%$ of them used it every day or several times a week. Only half of the users (53.5\%) considered themselves efficient users, but only $7.5 \%$ thought that they needed any instruction for using the device. To increase the efficiency of MPDs, users should develop their dictionary skills and MPD developers could improve the functions of MPDs (e.g. by providing an on-line hyperlink function).

\subsubsection{Boonmoh (2012)}

\begin{tabular}{ll}
\hline Type of investigation: & $\begin{array}{l}\text { Think-aloud protocol, observation, survey } \\
\text { (interview) }\end{array}$ \\
\hline Subjects: & 13 students \\
\hline Subject matter: & Utilisation of PEDs \\
\hline Result: & Participants read only the information on the \\
& PED screen and prefer bilingual dictionaries \\
\hline
\end{tabular}

Boonmoh's study aims to report how PEDs are used for writing and how successful students are in their consultation of PEDs. 13 Thai students of English took part (chosen from the 1,211 participants in Boonmoh/Nesi's study [2008]). They were asked to read a text in Thai and write a summary in English, using their PEDs. Additionally, five participants could review their summaries with the $6^{\text {th }}$ edition of the OALD. While writing the summaries, students reported the process in think-aloud protocols. In addition, the author took observation notes and interviewed the students afterwards. The study confirmed the assumption that only few students would scroll down the screen to read the whole dictionary entry. The participants preferred 
to use bilingual dictionaries although they considered monolingual dictionaries to be useful.

\subsubsection{Dziemianko (2012a)}

\begin{tabular}{ll}
\hline Type of investigation: & Test and survey (questionnaire) \\
\hline Subjects: & 86 students of English \\
\hline Subject matter: & $\begin{array}{l}\text { Usefulness of paper and electronic versions } \\
\text { of OALDCE7 }\end{array}$ \\
\hline Result: & Comparable results for both dictionary forms \\
\hline
\end{tabular}

Dziemianko replicated the studies she conducted in 2010 and 2011 to investigate the usefulness of the OALDCE7 in paper and electronic form and to compare the three studies. The same materials as in Dziemianko (2010 and 2011) were used. 86 Polish students of English took part, 42 of them consulted the paper version, 44 the electronic version. There were no significant differences between the scores of users of paper and electronic dictionary form.

\subsubsection{Lorentzen/Theilgaard (2012)}

\begin{tabular}{ll}
\hline Type of investigation: & $\begin{array}{l}\text { Survey (online questionnaire) and observa- } \\
\text { tion (logging and interview) }\end{array}$ \\
\hline Subjects: & 1,082 participants \\
\hline Subject matter: & Information on users of an online dictionary \\
\hline Result: & $\begin{array}{l}\text { Broad target group and different situations of } \\
\text { use }\end{array}$ \\
\hline
\end{tabular}

Lorentzen/Theilgaard describe the results of an online survey for the monolingual Danish dictionary Den Danske Ordbog, in which 1,082 users took part. The dictionary appeals to a well-educated target group at any age. The respondents - only 8 percent of them were new users - used the dictionary at work or in school, but at home as well. They often looked up information about meaning/use and spelling. 


\subsubsection{Heid/Zimmermann (2012)}

\begin{tabular}{ll}
\hline Type of investigation: & Survey (questionnaire) and test \\
\hline Subjects: & $\begin{array}{l}13 \text { students of translation science and spe- } \\
\text { cialized communication }\end{array}$ \\
\hline Subject matter: & $\begin{array}{l}\text { Suitable design of dictionary interface for } \\
\text { collocation retrieval }\end{array}$ \\
\hline Result: & $\begin{array}{l}\text { Translation students prefer the profile-based } \\
\text { dictionaries }\end{array}$ \\
\hline
\end{tabular}

Heid/Zimmermann's study deals with the most appropriate design for dictionary interfaces with regards to searching for collocations. They built different mock-ups of electronic dictionaries and tested them with 13 German students of translation science and specialized communication in a usability laboratory. Accompanying questionnaires completed the study. Three types of dictionary mock-ups were compared: a "one-shot" dictionary working as a search engine, a production-oriented profile-based dictionary and a reception-oriented profile-based dictionary. For the specific task of looking up collocations, the profile-based dictionaries were rated better by translation students. The participants preferred the possibilities they offered for focused search and the clear result presentation in contrast to the one-shot dictionary. However, the participants commented that they needed some time to familiarize themselves with the profile-based dictionaries.

\subsubsection{Wictorsen Kola (2012)}

\begin{tabular}{ll}
\hline Type of investigation: & Test \\
\hline Subjects: & 42 Norwegian pupils (15/16 years old) \\
\hline Subject matter: & $\begin{array}{l}\text { Morphological information in the monolin- } \\
\text { gual electronic dictionary Bokmalsordboka } \\
\text { and Nynorskordboka }\end{array}$ \\
\hline Result: & $\begin{array}{l}\text { Fewer mistakes when morphological infor- } \\
\text { mation is presented by a code and an exam- } \\
\text { ple word }\end{array}$ \\
\hline
\end{tabular}

Wictorsen Kola investigates whether pupils understand the morphological information given in the monolingual electronic dictionary Bokmålsordboka and Nynorskordboka. The dictionary uses codes representing certain inflectional patterns. 42 Norwegian pupils (15/16 years old) participated in the study. 73 percent of the exercises were answered correctly. Fewer mistakes occurred when morphological information was presented by a code and an example word. 


\subsubsection{Hult (2012)}

\begin{tabular}{ll}
\hline Type of investigation: & $\begin{array}{l}\text { Survey (online questionnaire) and observa- } \\
\text { tion (logging) }\end{array}$ \\
\hline Subjects: & $\begin{array}{l}863 \text { participants (questionnaires), 154,000 } \\
\text { log files of consultations, 160,600 log files of } \\
\text { users' navigation }\end{array}$ \\
\hline Subject matter: & Users and use of the dictionary \\
\hline Result: & $\begin{array}{l}\text { Advantage of combining different research } \\
\text { methods }\end{array}$ \\
\hline
\end{tabular}

Hult combines an online questionnaire and logfile analysis to obtain information on the users of the Swedish Lexin Dictionary, a monolingual learners' dictionary for immigrants. As the IP addresses of the questionnaires and the log files were merged, Hult was able to compare the statements in the questionnaire to real users' behaviour. 863 questionnaires were submitted. Unfortunately, no information is given about the results of the questionnaires, because they have still to be evaluated. Hult just mentions the fact that there were $154,000 \log$ files of consultations and 160,600 $\log$ files of users' navigation. She then presents the analysis of one particular user, combining the data of the questionnaire and the log files.

\section{Summary and future research}

This review of the individual studies on the use of electronic dictionaries shows that the majority of investigations are concerned with multilingual, and above all bilingual, dictionaries (e.g. Leffa, Corris et al., Selva/Verlinde, De Schryver/Joffe, De Schryver et al., Laufer/Levitzky-Aviad, Chen and Simonsen). In addition to this, there are those works in which aspects of comparison of bilingual and monolingual dictionaries are the focus (e.g. Aust et al., Laufer/Hill, Ernst-Martins, Petrylaite et al., Lew/Doroszewska, Dziemianko and Kaneta). This is connected to the fact that some of the studies concentrate in particular on the subject of vocabulary learning, for instance Leffa, Laufer/Hill, Laufer, Hill/Laufer, Lew/Doroszewska, Chen and Dziemianko. The majority of the results of these studies show that looking up several different types of information supports vocabulary retention. Only Bergenholtz/Johnsen, Haß and more recently Tono, Lorentzen/Theilgaard, Wictorsen Kola and Hult deal exclusively with research into the use of monolingual electronic dictionaries, if the two adapted dictionary extracts are counted as digital dictionaries.

As well as comparing bilingual and monolingual dictionaries, many investigations focus on contrasting electronic and printed dictionaries, such as Leffa, Aust et al., Laufer, Nesi (2000 b), Corris et al., Tono (2000), Winkler, Ernst-Martins, Boonmoh/Nesi, Petrylaite et al., Dziemianko and Chen (cf. Dziemianko 2012b for a sum- 
mary). The most important results are that participants look up more in electronic dictionaries and that access to the required information is quicker than in printed dictionaries. In many studies, the positive attitude of those questioned towards electronic dictionaries is also emphasized, which is often expressed in the users' higher level of satisfaction with the dictionary.

Studies into the use of electronic dictionaries have until now dealt mostly with documenting and evaluating user behaviour. In some cases (for example De Schryver/Joffe 2004), log files serve to close gaps in the lemmata in electronic dictionaries, if words which have been unsuccessfully looked up in the dictionary are amended (cf. De Schryver/Prinsloo and their concept of simultaneous feedback). Until now, users have been almost completely excluded from the process of constructing an electronic dictionary and the issue of how to present particular content. One exception is Haß, in whose investigation users judge the language used in the interface of the online dictionary elexiko. In addition, Simonsen (2009) investigates which type of data presentation the participants prefer.

of the numerous investigations presented here, only a proportion contain research into the use of online dictionaries. This arises from the fact that online dictionaries are only one kind of electronic dictionary. It is interesting in this context that academics from Asia (such as Boonmoh/Nesi, Boonmoh, Tono and Chen) carry out research into PEDs frequently, because these are particularly popular there, especially in Japan.

The methods used until now in research into the use of electronic dictionaries are less diverse than in research into dictionary use generally, and they are dominated by $\log$ file analysis. They are mostly special tests in the framework of research into dictionary use. User data logged over a longer period are evaluated by De Schryver/Joffe, Bergenholtz/Johnsen, De Schryver et al., Verlinde/Binon, Lorentzen/Theilgaard and Hult. Simonsen (2009 and 2011), Kaneta (2011) and Tono (2011) carry out observations using eye-tracking studies. A total of five studies Haß, Sánchez Ramos, Boonmoh/Nesi, Petrylaite et al. and Boonmoh - use questionnaires. Winkler, Chen and Bank combine a survey using a questionnaire with an experimental design. No other methods have been used to date. There is wide variation in the number of participants in the individual works. It ranges from five participants in Tono (2000) and Simonsen (2009) to 2,530 dictionary users in De Schryver/Joffe. On the one hand, the aforementioned concentration on logfile analysis makes use of the opportunities which arise from researching a type of dictionary which is still very new in terms of medium: there can hardly be another method which could supply more comprehensive, more exact and more reliable data on what users look up in electronic dictionaries than logfile analysis (see also Laufer/Hill 2000). On the other hand, this method also has various disadvantages: one problem is that the content of online dictionaries is often searched not by genuine dictionary users but by web crawlers, which should be excluded from the analyses. For example, Verlinde/Binon (2010: 1146) disclose in their logfile analysis of the 
Base lexical du français (BLF) that $90.49 \%$ of all accesses arise from web crawlers. With regard to human users, there are also data protection considerations. Furthermore, only existing dictionaries can be analyzed through the use of $\log$ files. Another problem is that by just analyzing log files, without additional data about the user (such as sociodemographic information), many questions remain unanswered (cf. Lew 2011 b: 13, cf. Hult 2012 for an attempt to combine log files with sociodemographic data). If, for example, there is no concrete information about the situation which has led to the user looking something up, then no statements can be made about what has really motivated the user to look something up. Nor can information about how satisfied the user is with what s/he has found in the dictionary be extracted in this way. For information of this kind, the user must be either asked directly or deliberately placed in a particular dictionary usage situation in which his/her behaviour can be seen. The same applies to issues of constructing and presenting individual dictionary entries, such as the use of menus, integrating visual representations or the language of the user interface. So through the use of eyetracking studies, in contrast to logfile analyses, it is possible to establish not only what the user is looking for, but also what movements his/her eyes make on the screen (cf. Simonsen 2011: 75). However, investigations which use eye-tracking have the disadvantage of being very expensive, for which reason often only an extremely small number of participants take part in them, such as six people in Kaneta (2011) or Simonsen (2011), of which in the end only three were included in the data analysis. This explains why eye-tracking studies have until now been unable to provide generalizable results in the context of research into dictionary use.

On the whole, a combination of different methods is advantageous, which combines elements of observation (eye-tracking and/or logfile analysis as an expression of concrete user behaviour), surveys (in the form of questionnaires or interviews, for information on background) and tests (construction of a particular dictionary usage situation which is identical for all participants). In this way, the advantages of the individual methods of investigation could be used specifically for different questions. This would provide results which above all could be more easily compared with each other in relation to the make-up of the participants and the dictionary usage situations. In recent years, the combination of different research methods in a single study has gained in importance.

This description of the current state of research into the use of electronic dictionaries makes it clear that in several areas there remains much to investigate. On the content side, both research into online dictionaries, in this case particularly monolingual dictionaries, and issues of user-friendly presentation of content have been investigated only a little or not at all. Overall, general questions on online dictionary use, such as expectations of and demands on online dictionaries in general, and questions of design, have been poorly addressed so far. On the methodological side, a combination of different procedures and participant groups would be desirable in the future, for the reasons outlined above. In the remaining articles in 
this volume, attempts to put this into practice in the framework of a project on research into the use of online dictionaries (www.using-dictionaries.info) at the Institute for German Language in Mannheim will be presented.

\section{Bibliography}

Atkins, S. B. T., \& Varantola, K. (1997). Monitoring dictionary use. International journal of Lexicography, 10(1), 1-45.

Aust, R., Kelley, M. J., \& Roby, W. (1993). The Use of Hyper-Reference and Conventional Dictionaries. Educational Technology Research and Development, 41(4), 63-73.

Bank, C. (2010). Die Usability von Online-Wörterbüchern und elektronischen Sprachportalen. Universität Hildesheim,, Hildesheim.

Barnhart, C. L. (1962). Problems in editing commercial monolingual dictionaries. In F. W. Householder \& S. Sapatora (Eds.), Problems in Lexicography (pp. 161-181). Bloomington: Indiana U. $P$.

Bergenholtz, H. (2011). 2. Access to and Presentation of Needs-adapted Data in Monofunctional Internet Dictionaries. In H. Bergenholtz \& P. A. Fuertes-Olivera (Eds.), e-Lexicography. The Internet, Digital Initiatives and Lexicography (pp. 30-45). London/New York: Continuum.

Bergenholtz, H., \& Johnsen, M. (2005). Log Files as a Tool for Improving Internet Dictionaries. Hermes. Journal of Language and Communication Studies, 34, 117-141.

Bergenholtz, H., \& Tarp, S. (2002). Die moderne lexikographische Funktionslehre. Diskussionsbeitrag zu neuen und alten Paradigmen, die Wörterbücher als Gebrauchsgegenstände verstehen. Lexicographica, 18, 253-263.

Bergenholtz, H., \& Varank, V. (2002, 2009). Den Danske Netordbog. In collaboration with Lena Lund, Helle Grønborg, Maria Bruun Jensen, Signe Rixen Larsen, Rikke Refslund, Mia Johnsen, Katja Å. Laursen, Sophie Leegaard and Maj H. Bukhave. Databank and Design: Richard Almind. Retrieved 15 October, 2009, from http://www.ordbogen.com/ordboger/ ddno/

Bogaards, P. (2003). Uses and users of dictionaries. In P. van Sterkenburg (Ed.), A Practical Guide to Lexikography (pp. 26-33). Amsterdam/Philadelphia: John Benjamins Publishing Company.

Boonmoh, A. (2011). Students' knowledge of pocket electronic dictionaries: recommendations for the students. In K. Akasu \& U. Satoru (Eds.), ASIALEX2011 Proceedings Lexicography: Theoretical and practical perspectives (pp. 66-75). Kyoto: Asian Association for Lexicography.

Boonmoh, A. (2012). E-dictionary Use under the Spotlight. Students' Use of Pocket Electronic Dictionaries for Writing. Lexikos, (22), 43-68.

Boonmoh, A., \& Nesi, H. (2008). A survey of dictionary use by Thai university staff and students, with special reference to pocket electronic dictionaries. Horizontes de Lingüistica Aplicada, $6(2), 79-90$.

Chen, Y. (2010). Dictionary use and EFL learning. A contrastive study of pocket electronic dictionaries and paper dictionaries. International Journal of Lexicography, 23(3), 275-306.

Chen, Y. (2011). Studies on bilingualized dictionaries: The user perspective. International Journal of Lexicography, 24(2), 161-197.

Chiari, I. (2006). Performance Evaluation of Italian Electronic Dictionaries: User's Needs and Requirements. In E. Corino, C. Marello, \& C. Onesti (Eds.), XII EURALEX International Congress. Turin.

Corris, M., Manning, C., Poetsch, S., \& Simpson, J. (2000). Bilingual Dictionaries for Australian Languages: User studies on the place of paper and electronic dictionaries. In U. Heid, S. Evert, E. Lehmann, \& C. Rohrer (Eds.), IX EURALEX International Congress (pp. 169-181). Stuttgart. 
De Schryver, G.-M. (2003). Lexicographers' Dreams in the Electronic Dictionary Age. International Journal of Lexicography, 16(2), 143-199.

De Schryver, G.-M., \& Joffe, D. (2003, 2009). Online Dictionary: Sesotho sa Leboa (Northern Sotho) English. Retrieved December 18, 2013, from http://africanlanguages.com/sdp/

De Schryver, G.-M., \& Joffe, D. (2004). On How Electronic Dictionaries are Really Used. In G. Williams \& S. Vessier (Eds.), Proceedings of the Eleventh EURALEX International Congress, Lorient, France, July 6th-10th (pp. 187-196). Lorient: Université de Bretagne Sud.

De Schryver, G.-M., Joffe, D., Joffe, P., \& Hillewaert, S. (2006). Do dictionary users really look up frequent words?-on the overestimation of the value of corpus-based lexicography. Lexikos, 16, 67-83.

De Schryver, G.-M., \& Prinsloo, D. J. (2000). The Concept of "Simultaneous Feedback": Towards a New Methodology for Compiling Dictionaries. Lexikos, (10), 1-31.

Diekmann, A. (2010). Empirische Sozialforschung. Grundlagen, Methoden, Anwendungen (4th ed.). Hamburg: Rowohlt.

Drápela, M. (2005). Three Online Learners' Dictionary. Retrieved December 18, 2013, from http://philologica.net/studia/20051231180000.htm

Dziemanko, A. (2010). Paper or electronic? The role of dictionary form in language reception, production and the retention of meaning and collocations. International Journal of Lexicography, 23(3), 257-273.

Dziemanko, A. (2011). Does dictionary form really matter? In K. Akasu \& U. Satoru (Eds.), ASIALEX2011 Proceedings Lexicography: Theoretical and practical perspectives (pp. 92-101). Kyoto: Asian Association for Lexicography.

Dziemanko, A. (2012a). On the use(fulness) of paper and electronic dictionaries. In S. Granger \& M. Paquot (Eds.), Electronic lexicography (pp. 319-341). Oxford: Oxford University Press.

Dziemanko, A. (2012b). Why one and two do not make three: Dictionary form revisited. Lexikos, (22), 195-216.

Engelberg, S., \& Lemnitzer, L. (2001). Lexikographie und Wörterbuchbenutzung. Tübimgen: Stauffenburg.

Engelberg, S., \& Müller-Spitzer, C. (forthcoming). Dictionary Portals. In R. H. Gouws, U. Heid, W. Schweickard, \& H. E. Wiegand (Eds.), Dictionaries. An international encyclopedia of lexicography. Supplementary volume: Recent Developments with Focus on Electronic and Computational Lexicography. Berlin/New York: De Gruyter.

Ernst-Martins, N. M. R. (2003). O uso de dicionärio on-line na compreensão de textos em língua española. Universidade católica de Pelotas, Pelotas. Retrieved July 11, 2013, from http://biblioteca.ucpel.tche.br/tedesimplificado/tde_busca/arquivo.php?codArquivo=185.

Europäische Akademie Bozen. (2002). ELDIT - Elektronisches Lern(er)wörterbuch Deutsch Italienisch. Retrieved July 11, 2013, from http://dev.eurac.edu:8081/MakeEldit1/Eldit.html

Gehrau, V. (2002). Die Beobachtung in der Kommunikationswissenschaft: methodische Ansätze und Beispielstudien. Konstanz: UVK-Verlagsgesellschaft.

Hartmann, R. R. K. (1987). Wozu Wörterbücher? Die Benutzungsforschung in der zweisprachigen Lexikographie. Lebende Sprachen, 32(4), 154-156.

Hartmann, R. R. K. (1989). Sociology of the Dictionary User: Hypotheses and Empirical Studies. In F. J. Hausmann, O. Reichmann, H. E. Wiegand, \& L. Zgusta (Eds.), Wörterbücher-Dictionaries Dictionnaires. Ein internationales Handbuch zur Lexikographie (Vol. 1, pp. 102-111). Berlin, New York: de Gruyter.

Hartmann, R. R. K. (2000). European Dictionary Culture. The Exeter Case Study of Dictionary Use among University Students, against the Wider Context of the Reports and Recommendations of the Thematic Network Project in the Area of Languagew 1996-1999. In U. Heid, S. Evert, E. Lehmann, \& C. Rohrer (Eds.), IX EURALEX International Congress (pp. 385-391). Stuttgart. 
$\mathrm{Haß,}$ U. (2005). Nutzungsbedingungen in der Hypertextlexikografie. Über eine empirische Untersuchung. In D. Steffens (Ed.), Wortschatzeinheiten: Aspekte ihrer (Be) schreibung. Dieter Herberg zum 65. Geburtstag (pp. 29-41). Mannheim: Institut für Deutsche Sprache.

Hausmann, F. J. (1989). Wörterbuchtypologie. In F. J. Hausmann, O. Reichmann, H. E. Wiegand, \& L. Zgusta (Eds.), Wörterbücher - Dictionaries - Dictionnaires. Ein Internationales Handbuch zur Lexikographie (Vol. 1, pp. 968-981). Berlin,New York: de Gruyter.

Heid, U. (2011). Electronic Dictionaries as Tools: Towards an Assessment of Usability. In P. A. Fuertes-Olivera \& H. Bergenholtz (Eds.), e-Lexicography. The Internet, Digital Initiatives and Lexicography (pp. 285-304). London: Continuum.

Heid, U., \& Zimmermann, J. T. (2012). Usability testing as a tool for e-dictionary design: collocations as a case in point. In J. M. Torjusen \& R. V. Fjeld (Eds.), Proceedings of the 15th EURALEX International Congress 2012, Oslo, Norway, 7 - 11 August 2012 (pp. 661-671). Oslo.

Heuberger, R. (2000). Monolingual dictionaries for foreign learners of English: a constructive evaluation of the state-of-the-art reference works in book form and on CD-ROM. Wien: Braumüller.

Hill, M., \& Laufer, B. (2003). Type of task, time-on-task and electronic dictionaries in incidental vocabulary acquisition. IRAL-International Review of Applied Linguistics in Language Teaching, 41(2), 87-106.

Hillewaert, S., Joffe, P., \& De Schryver, G.-M. (2004, 2006). Swahili - English Dictionary (Kamusi ya Kiswahili - Kiingereza). Retrieved December 18, 2013, from http://africanlanguages.com/swahili/.

Höhne, S. (1991). Die Rolle des Wörterbuchs in der Sprachberatung. Zeitschrift Für Germanistische Linguistik, 19(3), 293-321.

Hornby, A. S., \& Wehmeier, S. (2004). Oxford Advanced Learner's English-Chinese Dictionary. Beijing: The Commercial Press.

Hulstijn, J. H., \& Atkins, B. T. S. (1998). Empirical research on dictionary use in foreign-language learning: survey and discussion. In B. T. S. Atkins (Ed.), Using Dictionaries (pp. 7-19). Tübingen: Max Niemeyer Verlag.

Hult, A.-K. (2012). Old and New User Study Methods Combined - Linking Web Questionnaires with Log Files from the Swedish Lexin Dictionary. Oslo. Universitetet i Oslo, Institutt for lingvistiske og nordiske studier. In J. M. Torjusen \& R. V. Fjeld (Eds.), Proceedings of the 15th EURALEXInternational Congress 2012 (pp. 922-928). Oslo, Norway. Retrieved December 18, 2013, from http://www.euralex.org/elx_proceedings/Euralex2012/pp922-928\%20Hult.pdf.

Institut für Deutsche Sprache (Ed.). (2003ff), elexiko : Online-Wörterbuch zur deutschen Gegenwartssprache. Retrieved December 18, 2013, from www.elexiko.de.

Kaneta, T. (2011). Folded or unfolded: eye-tracking analysis of $L 2$ learner's reference behavior with different types of dictionary interfaces. In K. Akasu \& U. Satoru (Eds.), ASIALEX2011 Proceedings Lexicography: Theoretical and practical perspectives (pp. 219-224). Kyoto: Asian Association for Lexicography.

Klosa, A., Lemnitzer, L., \& Neumann, G. (2008). Wörterbuchportale-Fragen der Benutzerführung. Lexikographische Portale Im Internet. OPAL Sonderheft, 1, 5-35.

Krajka, J. (2004). Electronic Dictionaries as Teaching and Learning Tools - Possibilities and Limitations. In M. C. Campoy Cubillo \& P. Safont Jordà (Eds.), Computer-mediated lexicography in the foreign language learning context (pp. 29-46). Castellón de la Plana: Universitat Jaume I.

Laufer, B., \& Hadar, L. (1997). Assessing the Effectiveness of Monolingual, Bilingual, and "Bilingualised" Dictionaries in the Comprehension and Production of New Words. Modern Language journal, 81(2), 189-196.

Laufer, B., \& Hill, M. (2000). What lexical information do L2 learners select in a CALL dictionary and how does it affect word retention? Language Learning \& Technology, 3(2), 58-76. 
Laufer, B., \& Levitzky-Aviad, T. (2006). Examining the effectiveness of "bilingual dictionary plus"-a dictionary for production in a foreign language. International Journal of Lexicography, 19(2), 135-155.

Law, W. (2011). Mobile Phone Dictionary: Friend or Foe? A User Attitude Survey of Hong Kong Translation Students. In K. Akasu, U. Satoru, \& K. Li (Eds.), ASIALEX2011 Proceedings Lexicography: Theoretical and practical perspectives (pp. 303-312). Kyoto: Asian Association for Lexicography.

LDOCE Online - Longman English Dictionary Online. (2013). Retrieved December 11, 2013, from http://www.ldoceonline.com/

Leffa, V. J. (1993). Using an Electronic Dictionary to Understand Foreign Language Texts. Trabalhos Em Linguistica Aplicada, 21, 19-29.

Lemnitzer, L. (2001). Das Internet als Medium für die Wörterbuchbenutzungsforschung. In I. Lemberg, B. Schröder, \& A. Storrer (Eds.), Chancen und Perspektiven computergestützer Lexikographie. Hypertext, Internet und SGML/XML für die Produktion und Publikation digitaler Wörterbücher (pp. 247-254). Tübingen: Max Niemeyer Verlag.

Lew, R. (2011). Studies in Dictionary Use: Recent Developments. International Journal of Lexicogra phy, 24(1), 1-4.

Lew, R. (2011). User studies: Opportunities and limitations. In K. Akasu \& U. Satoru (Eds.), ASIALEX2011 Proceedings Lexicography: Theoretical and practical perspectives (pp. 7-16). Kyoto: Asian Association for Lexicography.

Lew, R., \& Doroszewska, J. (2009). Electronic dictionary entries with animated pictures: Lookup preferences and word retention. International Journal of Lexicography, 22(3), 239-257.

Limited, M. P. (2009, 2011). Macmillan Dictionary and Thesaurus: Free English Dictionary Online. Retrieved July 11, 2011, from http://www.macmillandictionary.com/

Lorentzen, H. (2012). Online dictionaries - how do users find them and what do they do once they have? In L. Theilgaard (Ed.), Proceedings of the 15th EURALEX International Congress 2012, Oslo, Norway, $7-11$ August 2012 (pp. 654-660). Oslo: Universitetet i Oslo, Institutt for lingvistiske og nordiske studier. Retrieved December 18, 2013, from http://www.euralex.org/elx_proceedings/Euralex2012/pp626-639\%20Sharifi.pdf

Loucky, J. P. (2005). Combining the benefits of electronic and online dictionaries with CALL web sites to produce effective and enjoyable vocabulary and language learning lessons. Computer Assisted Language Learning, 18(5), 389-416.

Macmillan Publishers Limited. (2009, 2011). Macmillan Dictionary and Thesaurus: Free English Dictionary Online. Retrieved July 11, 2011, from http://www.macmillandictionary.com/

Mann, M. (2010). Internet-Wörterbücher am Ende der „Nullerjahre“: Der Stand der Dinge. Eine vergleichende Untersuchung beliebter Angebote hinsichtlich formaler Kriterien unter besonderer Berücksichtigung der Fachlexikographie. In Lexicographica (pp. 19-46). De Gruyter.

Müller-Spitzer, C. (2007). Der lexikografische Prozess: Konzeption für die Modellierung der Datenbasis. Tübingen: Narr.

Müller-Spitzer, C. (2008). Research on Dictionary Use and the Development of User-Adapted Views. In A. Storrer, A. Geyken, A. Siebert, \& K.-M. Würzner (Eds.), Text Resources and Lexical Knowledge Selected Papers from the 9 th Conference on Natural Language Processing KONVENS 2008 (pp. 223-238). Berlin: de Gruyter.

Nesi, H. (1999). A User's Guide to Electronic Dictionaries for Language Learners. International journal of Lexicography, 12(1), 55-66.

Nesi, H. (2000a). Electronic dictionaries in second language vocabulary comprehension and acquisition: The state of the art. In U. Heid, S. Evert, E. Lehmann, \& C. Rohrer (Eds.), IX EURALEX International Conference (pp. 839-847). Stuttgart. 
Nesi, H. (2000b). On screen or in print? Students' use of a learner's dictionary on CD-ROM and in book form. In P. Howarth \& R. Herington (Eds.), Issues in EAP Learning Technologies (pp. 106114). Leeds: Leeds University Press.

Nord, B. (2002). Hilfsmittel beim Übersetzen: eine empirische Studie Zum Rechercheverhalten professioneller Übersetzer. Frankfurt: Peter Lang.

OWID - Online-Wortschatz-Informationssystem Deutsch. (2008, 2013). Retrieved December 18, 2013, from http://www.owid.de/

Petrylaitė, R., Vaškelienė, D., \& Véžytė, T. (2008). Changing Skills of Dictionary Use. Studies about Languages, $12,77-82$.

Ripfel, M., \& Wiegand, H. E. (1988). Wörterbuchbenutzungsforschung. Ein kritischer Bericht. In H. E. Wiegand (Ed.), Studien zur neuhochdeutschen Lexikographie VI (pp. 491-520). Hildesheim u.a.: Georg Olms Verlag.

Roby, W. B. (1999). What's in a gloss. Language Learning \& Technology, 2(2), 94-101.

Sánchez Ramos, M. M. (2005). Research on dictionary use by trainee translators. Translation Jour$n a l, 9(2)$.

Schnell, R., Hill, P. B., \& Esser, E. (2009). Methoden der empirischen Sozialforschung. München: oldenbourg, $R$.

Selva, T., \& Verlinde, S. (2002). L'utilisation d'un dictionnaire électronique: une étude de cas. In A. Braasch \& C. Povlsen (Eds.), XEURALEXInternational Conference (pp. 773-781). Kopenhagen.

Simonsen, H. K. (2009). Vertical or Horizontal? That is the Question: An Eye-Track Study of Data Presentation in Internet Dictionaries. Kopenhagen: Copenhagen Business School.

Simonsen, H. K. (2011). User Consultation Behaviour in Internet Dictionaries: An Eye-Tracking Study. Hermes. Journal of Language and Communication Studies, 46, 75-101.

Sinclair, J. (Ed.). (2009). Collins COBUILD advanced dictionary. Boston, MA: Heinle Cengage Learning.

Storrer, A., \& Freese, K. (1996). Wörterbücher im Internet. Deutsche Sprache, 24(2), 97-153.

Tarp, S. (2008). Lexicography in the borderland between knowledge and non-knowledge: general lexicographical theory with particular focus on learner's lexicography. Tübingen: Max Niemeyer Verlag.

Tono, Y. (2000). On the effects of different types of electronic dictionary interfaces on L2 learners' reference behaviour in productive/receptive tasks. In U. Heid, S. Evert, E. Lehmann, \& C. Rohrer (Eds.), IX EURALEXInterntational Conference (pp. 855-861). Stuttgart.

Tono, Y. (2004). Research on the use of electronic dictionaries for language learning: Methodological Considerations. In M. C. Campoy Cubillo \& M. P. Safont Jordá (Eds.), Computer-mediated lexicography in the foreign language learning context (pp. 13-27). Castelló de la Plana: Universitat Jaume I.

Tono, Y. (2009). Pocket Electronic Dictionaries in Japan: User Perspectives. In H. Bergenholtz, S. Nielsen, \& S. Tarp (Eds.), Lexicography at a Crossroads: Dictionaries and Encyclopedias Today, Lexicographical Tools Tomorrow (pp. 33-67). Bern u.a.: Peter Lang.

Tono, Y. (2011). Application of Eye-Tracking in EFL Learners. Dictionary Look-up Process Research.'International Journal of Lexicography, 23.

Tribble, C. (2003). Five electronic learners' dictionaries. ELT Journal, 57(2), 182-197.

Verlinde, S., \& Binon, J. (2010). Monitoring Dictionary Use in the Electronic Age. In A. Dykstra \& T. Schoonheim (Eds.), Proceedings of the XIV Euralex International Congress (pp. 1144-1151). Ljouwert: Afûk.

Verlinde, S., Peeters, G., \& Wielants, J. (n.d.). Lexical Database for French (Base lexicale du français - BLF). Retrieved December 18, 2013, from http://ilt.kuleuven.be/blf/

Welker, H. A. (2006). O uso de dicionários: panorama geral das pesquisas empíricas. Brasília, DF: Thesaurus. 
Welker, H. A. (2006). Pesquisando o uso de dicionários. Linguagem \& Ensino, 9(2), 223-243.

Welker, H. A. (2008). Sobre o Uso de Dicionarios. Anais Do Celsul, 1-17.

Wictorsen Kola, A.-K. (2012). A study of pupils' understanding of the morphological information in the Norwegian electronic dictionary Bokmålsordboka and Nynorskordboka. In I. M. Torjusen $\&$ R. V. Fjeld (Eds.), Proceedings of the 15th EURALEX International Congress 2012 (pp. 672-675). Oslo, Norway. Retrieved from http://www.euralex.org/elx_proceedings/Euralex2012/pp922$928 \% 20$ Hult.pdf

Wiegand, H. E. (1987). Zur handlungstheoretischen Grundlegung der Wörterbuchbenutzungsforschung. Lexicographica, 3, 178-227.

Wiegand, H. E. (1998). Wörterbuchforschung: Untersuchungen zur Wörterbuchbenutzung, zur Theorie, Geschichte, Kritik und Automatisierung der Lexikographie. Berlin u.a.: Walter De Gruyter.

Wiegand, H. E. (2008). Wörterbuchbenutzung bei der Übersetzung. Möglichkeiten ihrer Erforschung.

Wiegand, H. E., Beißwenger, M., Gouws, R. H., Kammerer, M., Storrer, A., \& Wolski, W. (2010). Systematische Einführung. In Wörterbuch zur Lexikographie und Wörterbuchforschung. 1st vol.: Systematische Einführung (pp. 1-121). de Gruyter. Retrieved from http://books.google.de/books?id=Bg9tcgAACAA]

Winkler, B. (1998). Electronic Dictionaries for Learners of English. Retrieved from http://web.warwick.ac.uk/fac/soc/CELTE/PG_conference/B_Winkler.htm

Winkler, B. (2001a). English learners' dictionaries on CD-ROM as reference and language learning tools. ReCALL, 13(02), 191-205.

Winkler, B. (2001b). Students working with an English learners' dictionary on CD-ROM. In ITMELT (pp. 227-254). Hong Kong, The English Language Centre, The Hong Kong Polytechnic University. Retrieved from http://elc.polyu.edu.hk/conference/papers2001/winklet.htm

Zöfgen, E. (1994). Lernerwörterbücher in Theorie und Praxis. Ein Beitrag zur Metalexikographie mit besonderer Berücksichtigung des Französischen. Tübingen: Max Niemeyer. 